\title{
The recent distribution of endemic, disjunct and globally uncommon birds in the forests of Kerala State, south-west India
}

\author{
V. J. ZACHARIAS and ANTHONY J. GASTON
}

\section{Summary}

We surveyed the avifaunas of 24 forest areas in Kerala State, south-western India, over the period 1973-1997, recording 309 species. We give details here of distributions and status for all species endemic to South Asia and all those having isolated populations, disjunct from conspecifics in northern India (disjunct species). Most bird species found in Kerala that are endemic to southern India, or form disjunct populations, occur in forest habitats. Those species endemic to the Western Ghats (passerines), or constituting disjunct populations (raptors) tend to have more restricted occurrence than other forest birds. For the passerines this is because they are mainly confined to high elevation forests and grasslands: rather restricted habitats in Kerala. The raptors may be more dependent than other species on large areas of forest and hence may have suffered from recent reductions in forest cover. Current trends in forest clearance for agriculture and plantations and encroachment by settlers, threaten especially the birds of low and middle altitude forests. The present status of such birds as Malabar Pied Hornbill Anthracoceros coronatus, Great Eared Nightjar Eurostopodus macrotis, Lesser Coucal Centropus bengalensis and White-bellied Blue Flycatcher Cyornis pallipes seems to be markedly worse than that described by Ali (1969) for the 1930s. These species, as well as Dollarbird Eurystomus orientalis and Black-crested Baza Aviceda leuphotes, are patchily distributed at low densities and may be vulnerable to extirpation from local areas. Higher altitude habitats, where many endemics occur, cover smaller areas, but are less threatened. However, some species occurring at low densities (Rufous-bellied Eagle Hieraaetus kienerii, White-bellied Shortwing Brachypteryx major, Black-and-orange Flycatcher Ficedula nigrorufa, Broad-tailed Grassbird Schoenicola platyura) may be vulnerable to extirpation or extinction in the long term. Kerala has a large network of protected areas (National Parks, Sanctuaries). Effective protection of those areas should be sufficient to maintain most species, although the coverage of low altitude forest is poor and remaining fragments should be carefully protected. There is continuous pressure on all habitats and bird populations will need to be carefully monitored in future if Kerala's endemic and disjunct populations are to be maintained.

\section{Introduction}

The Western Ghats are the highest hills of the Indian peninsula and support 41 species of endemic birds. In addition, their avifauna includes more than 40 species (the exact number is dependent on definition, see below) of "disjuncts"; populations that are isolated from other populations of conspecifics elsewhere in India; usually in the Eastern Ghats or in the Himalayas (Ali 1969). Disjunct 
species are of special interest because they may represent relict outliers of formerly continuous populations, interconnected during the Pleistocene (Ali 1949, 1969). Some of the species involved are represented in the Western Ghats by endemic sub-species: all are resident. The Western Ghats are considered an internationally important area for avian species diversity and support 13 endemic species of birds considered to be "near-threatened" globally (Collar et al. 1994).

Much of the natural forest remaining in the southern Western Ghats is located in the State of Kerala, where surveys were carried out in 1933-1935 by Ali (1969). Those surveys covered only the former princely states of Travancore and Cochin and hence the Malabar region of northern Kerala was not included. Little published information is available on the birds of Malabar, apart from the work of Davison (1883). Some aspects of the avifauna of adjacent Uttara Kannada district of Karnataka have been described recently by Daniels et al. (1990).

Since 1973, we have been carrying out surveys of birds in the state to assess their recent status and the effects of changes in land use. Our primary goal has been to assess the current distribution of globally uncommon (see below), endemic and disjunct species to provide a background for prioritizing conservation action. We present the results of these surveys and use the distributional information obtained to make some generalizations about the ecology of the rarer species and the reasons for their rarity.

\section{Study area and methods}

\section{Forest types}

Natural forests of the Western Ghats in Kerala range from dry deciduous through moist evergreen (Champion and Seth 1968). All areas to the west of the main ranges originally supported evergreen or semi-evergreen forest, while the rainshadow effect of the hills created drier forests on the eastern slopes. The transition is very abrupt in places (e.g. Wynaad Sanctuary). Currently, many areas to the west of the Ghats support degraded evergreen forest that has many characteristics of moist deciduous, or even dry deciduous forest, so the original classifications are difficult to apply. Most remaining areas of non-plantation forest occur at middle and high altitudes, especially along the crest of the Western Ghats, and around the headwaters of major rivers, such as the Periyar (Figure 1). The highest forests consist of characteristic evergreen associations known as sholas, often bordered by dense thickets of Strobilanthes shrubs. The summits of the ranges are mainly grassland maintained by periodic burning; probably an ancient landscape feature.

All of the forests of Kerala have been much degraded by human activities in recent decades, with forests changing from evergreen towards deciduous as they are opened up. As a result of recent encroachments by agriculturalists, and the opening up of forests through widespread timber felling, few forest blocks are now unmixed. Probably all forest areas include patches of both evergreen and moist deciduous type. Large areas of formerly semi-evergreen and moist deciduous forest have been felled and planted with teak Tectona grandis. In addition, large areas of high-altitude grasslands have been taken over for Eucalyptus plantations. Some of these plantations coexist with natural grasses, creating semi- 


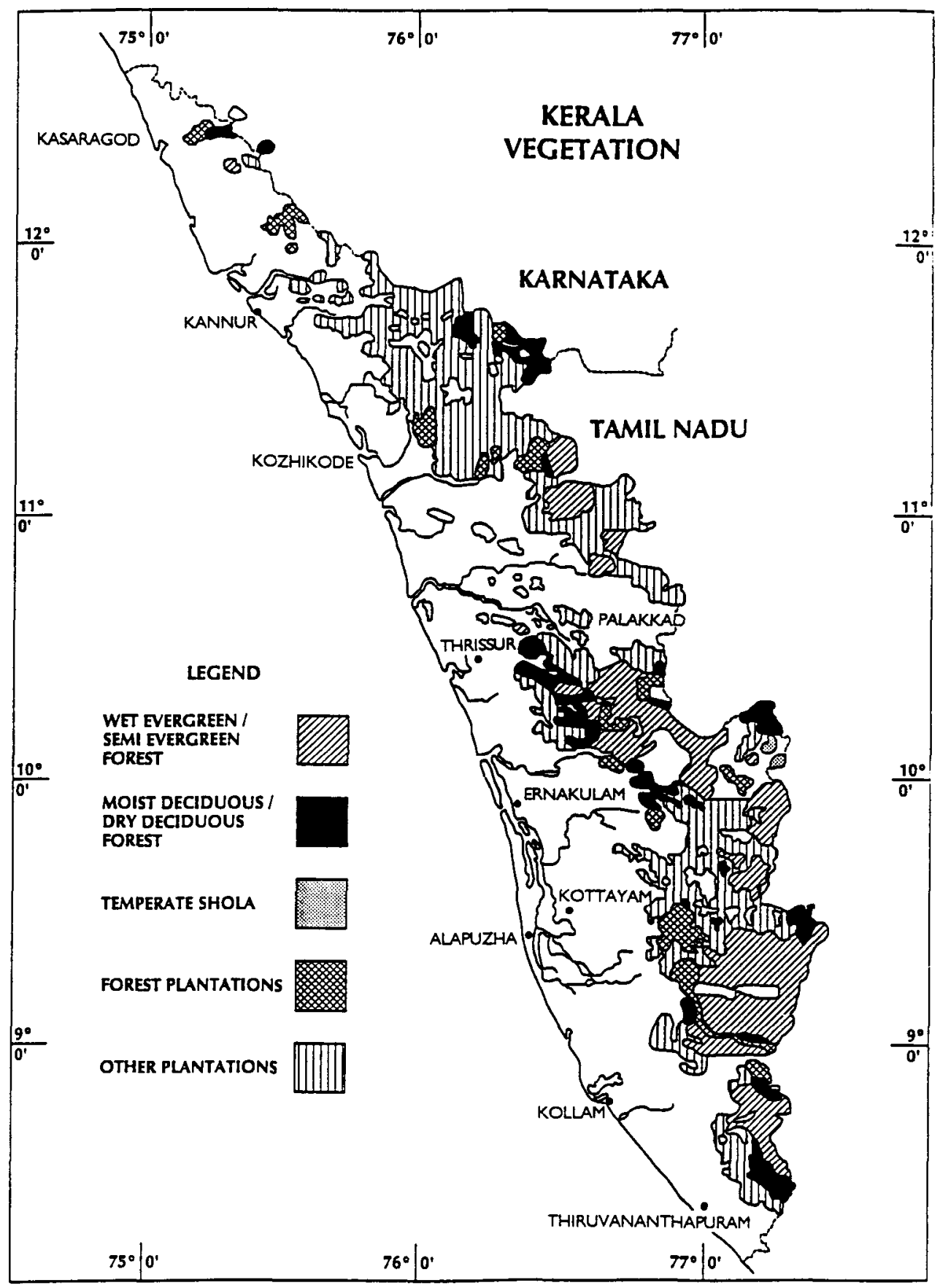

Figure 1. Forest types of Kerala (information from Centre for Earth Science Studies, Survey of India, 1984). 
wooded grasslands. Pure natural ecosystems, untouched by felling, grazing or planting, are relatively rare, even within protected areas.

Within Kerala, the high hills of the Western Ghats are divided into two blocks by the Palakkad (Palghat) Gap, a significant pass at latitude $10^{\circ} 30^{\prime} \mathrm{N}$. The area contained within this pass has been cultivated for many years and both the relatively low altitude $(<200 \mathrm{~m})$ and the lack of forest cover probably create significant barriers to the movement of forest birds across the gap. Where appropriate, we have commented on the status of species both north and south of this break. A less pronounced hiatus in forest cover occurs at the Achankovil Gap $\left(8^{\circ} 5^{\prime} \mathrm{N}\right)$, although this pass is higher and narrower than the Palakkad Gap.

\section{Fieldwork}

Surveys were carried out by either or both of the authors, sometimes in company with others, in 24 forest areas of Kerala (Table 1, Figure 2). All bird species seen or heard were recorded and numbers of less common species were noted. Each survey consisted of a visit of a minimum of three days duration, covering as large a range of forest types as we could find in the area, and also adjacent high-altitude grasslands, where present. In addition, we surveyed plantations and areas of afforestation, where these were adjacent to natural forests. However, in this paper, we do not include large blocks of plantations away from natural forests. Some areas were surveyed repeatedly over several years, especially the Thekkady areas (East and West), Nelliampathy, Nilambur and areas in Wynaad (Thirunelli, Sultan's Battery, Wynaad Ghats). A list of records from Wynaad has already been published (Zacharias and Gaston 1993), as have a few species maps based on preliminary data (Gaston and Zacharias 1996).

Surveys were repeated in all seasons, where possible (winter, December-January; hot season, February-May; monsoon, June-September; and post-monsoon, October-November), although this was not achieved for all areas. We managed four-seasons surveys in 14 areas $(3,5-12,15-17,19,20)$ which included all the major forest blocks in Kerala. Numerical abundance was estimated on the following scale: abundant, seen or heard in double figures daily; common, seen or heard daily; uncommon, seen or heard on more than $30 \%$ of days, but not daily; rare, seen or heard on less than $30 \%$ of days. Altitudes were classified as low $(<500 \mathrm{~m})$, middle $(500-1000 \mathrm{~m})$ or high $(>1000 \mathrm{~m})$. In addition to our own observations, we mapped historical records where these occurred in areas where we did not record the species concerned. For the period since 1973, we have mapped only our own records, to maintain consistency, but other recent information is included in the text.

\section{Species classifications}

In analysing our distributional data, we aggregated species into the following categories: (1) waterbirds (grebes, herons, cormorants, darters, storks, ducks); (2) birds of prey and owls; (3) game birds and rails; (4) shorebirds, gulls and terns; (5) other non-passerines (pigeons, parakeets, cuckoos, nightjars, swifts, trogons, kingfishers, rollers, hornbills, barbets and woodpeckers); and (6) passerines. Spe- 
Table 1. Localities surveyed and habitat descriptions (PA, Protected Area)

\begin{tabular}{|c|c|c|}
\hline Locality & Altitude $(\mathrm{m})$ & Description \\
\hline (1) Parappa & $60-100$ & $\begin{array}{l}\text { Deciduous forest, patchy, surrounded by cultivation; peren- } \\
\text { nial stream }\end{array}$ \\
\hline (2) Konnakkad & $400-800$ & $\begin{array}{l}\text { Evergreen, semi-evergreen patches, grasslands, some cul- } \\
\text { tivation; streams; adjacent to Coorg, Karnataka }\end{array}$ \\
\hline (3) Thirunelli & $900-1,200$ & $\begin{array}{l}\text { Evergreen, semi-evergreen, sholas, grasslands; eucalyptus } \\
\text { plantation and cultivation at lower altitudes; perennial } \\
\text { streams }\end{array}$ \\
\hline (4) Periya Ghats & $400-700$ & Semi-evergreen, moist-deciduous, swamps, disturbed \\
\hline (5) Sultan's Battery & 700 & $\begin{array}{l}\text { Moist deciduous and teak and eucalyptus plantations, scat- } \\
\text { tered swamps and adjacent cultivation; E slopes of ghats } \\
\text { (PA) }\end{array}$ \\
\hline (6) Wynaad Ghats & $600-1,000$ & $\begin{array}{l}\text { Semi-evergreen and moist deciduous; coffee, cardamom } \\
\text { plantations; Pookote Lake, perennial streams }\end{array}$ \\
\hline (7) Nilambur & $60-500$ & $\begin{array}{l}\text { Semi-evergreen and moist deciduous patches, grasslands, } \\
\text { teak plantations; Chaliyar River; at } W \text { foot of ghats (PA, part) }\end{array}$ \\
\hline (8) Silent Valley & $700-1,000$ & $\begin{array}{l}\text { Evergreen and semi-evergreen, sholas and grasslands; Kun- } \\
\text { thipuzha River (PA) }\end{array}$ \\
\hline (9) Dhoni & $100-200$ & $\begin{array}{l}\text { Semi-evergreen, moist deciduous and deciduous, rubber and } \\
\text { coconut plantations; selection felling in last century; peren- } \\
\text { nial stream; N side of Palakkad Gap }\end{array}$ \\
\hline (10) Trichur Ghats & $40-100$ & $\begin{array}{l}\text { Deciduous forest patches, teak and rubber plantations; culti- } \\
\text { vation }\end{array}$ \\
\hline (11) Nelliampathy & $700-1,200$ & $\begin{array}{l}\text { Evergreen, semi-evergreen and moist deciduous, sholas, } \\
\text { grasslands; tea, coffee and cardamom; perennial streams }\end{array}$ \\
\hline (12) Parambikulam & $300-700$ & $\begin{array}{l}\text { Semi-evergreen, moist deciduous, and deciduous; teak } \\
\text { plantations; streams, ponds and swamps (PA) }\end{array}$ \\
\hline (13) Sholayar & $60-300$ & $\begin{array}{l}\text { Evergreen, semi-evergreen and moist deciduous; planta- } \\
\text { tions; perennial streams }\end{array}$ \\
\hline (14) Edamalayar & $60-200$ & $\begin{array}{l}\text { Evergreen, semi-evergreen and moist deciduous; teak } \\
\text { plantations; reservoir lake, river }\end{array}$ \\
\hline (15) Thattekkad & 60 & $\begin{array}{l}\text { Semi-evergreen and moist-deciduous; teak plantation; river } \\
\text { (PA) }\end{array}$ \\
\hline (16) Munnar & $900-2,000$ & $\begin{array}{l}\text { Evergreen, semi-evergreen, sholas, grasslands; tea and car- } \\
\text { damom plantations; river (PA, part) }\end{array}$ \\
\hline (17) Pambadumpara & $700-900$ & $\begin{array}{l}\text { Degraded semi-evergreen patches; coffee and cardamom } \\
\text { plantations, cultivation; streams }\end{array}$ \\
\hline (18) Kottayam East & $40-200$ & Grassland, rubber plantation; river \\
\hline (19) Periyar East & $900-2,000$ & $\begin{array}{l}\text { Sholas, evergreen, semi-evergreen, and moist deciduous and } \\
\text { grasslands; reservoir lake (PA) }\end{array}$ \\
\hline (20) Periyar West & $800-1,400$ & $\begin{array}{l}\text { Sholas, evergreen, semi-evergreen, and moist deciduous and } \\
\text { grasslands; eucalyptus; Periyar River (PA) }\end{array}$ \\
\hline (21) Ranni & $60-200$ & $\begin{array}{l}\text { Semi-evergreen and moist deciduous; teak and rubber } \\
\text { plantations, cultivation: Pamba River and streams }\end{array}$ \\
\hline (22) Tenmalai & $100-600$ & $\begin{array}{l}\text { Evergreen and moist deciduous forest; teak plantation; river } \\
\text { (PA) }\end{array}$ \\
\hline (23) Ponmudi & $700-1200$ & $\begin{array}{l}\text { Evergreen, semi-evergreen and moist-deciduous, and grass- } \\
\text { land; tea plantations }\end{array}$ \\
\hline (24) Agastiamalai & $200-1,300$ & $\begin{array}{l}\text { Sholas, evergreen, semi-evergreen, moist deciduous and } \\
\text { grasslands; perennial streams (PA, part) }\end{array}$ \\
\hline
\end{tabular}




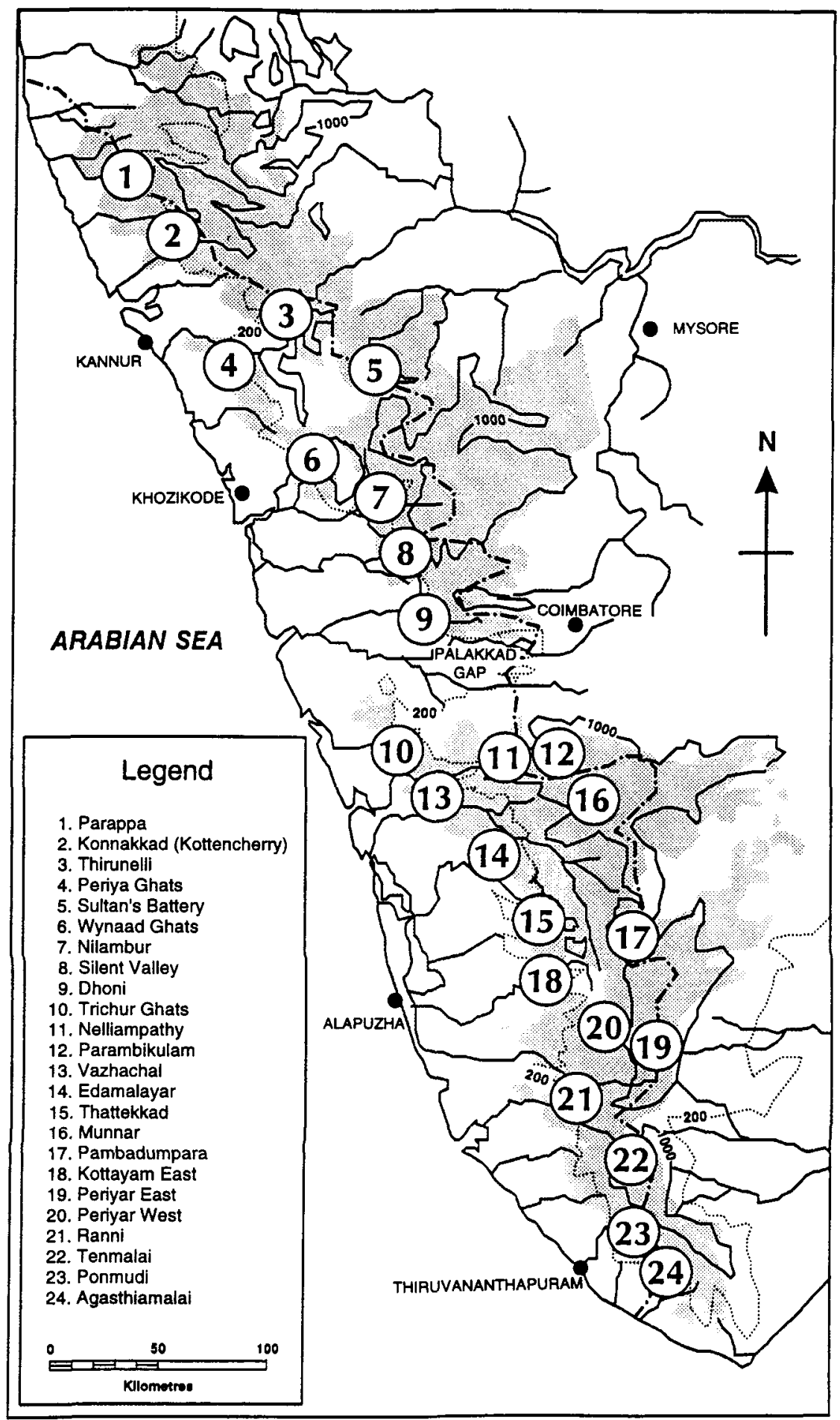

Figure 2. Map of Kerala State, showing study sites and main area of forest (shaded). 
cies were considered "lowland" if not recorded above $500 \mathrm{~m}$, and "upland" if not recorded below $1000 \mathrm{~m}$.

Species were categorized as resident or migrant. Endemic species were divided into those endemic to the Indian subcontinent (South Asian endemics, SAE), a group that includes some birds of open country; and those endemic to the Western Ghats and other peninsular hills, and Sri Lanka (Western Ghats endemics, WGE). Most of these have their main populations in the Western Ghats. Disjunct species were likewise divided into those with a very marked range disjunction without any intermediate populations between the Western Ghats and the Himalayas (isolated disjuncts, ID: e.g. Rufous-bellied Eagle Hieraaetus kienerii), and those connected via pockets in the Eastern Ghats and the higher hills of Madhya Pradesh (quasi-disjuncts, QD: e.g. Vernal Hanging Parrot Loriculus vernalis). The definition of quasi-disjunct species is to some extent arbitrary, especially in the absence of recent distributional information for many parts of India. It is possible that the Western Ghats populations of other species are now isolated from those elsewhere in the peninsula, because of deforestation in recent decades. Our definitions are based largely on the range maps and distributional information given by Ali and Ripley (1987). Nomenclature follows Inskipp et al. (1996).

Aparf from high-altitude grasslands, Kerala was probably completely covered by dense forests prior to the advent of agriculture (Randhawa 1980). Consequently, our surveys should give a good idea of the recent distribution of species native to Kerala. Some species that occur mainly in lowland agricultural areas will also have been inadequately sampled by our surveys. However, many of these species are common birds of agricultural land throughout India and are neither endemic nor disjunct (e.g. Common Myna Acridotheres tristis, Black Drongo Dicrurus adsimilis). We believe that, by concentrating on forest areas and their adjacent high-altitude grasslands, we obtained an adequate overview of the status of most disjunct and endemic species in Kerala, nearly all of which are primarily birds of forest or high-altitude grasslands.

\section{Results}

Distribution maps presented (Figures 3-71) cover 69 species. We have excluded waterbirds, rails, shorebirds, gulls and terns, and a few open-country passerines, as our records are unlikely to give a useful idea of their distributions in Kerala. We did not map six species that we recorded at only one or two sites, and eight that we recorded at more than 21 sites: for these species the pattern of records was easier to summarize in the text. We have included maps for three raptors that are neither disjunct nor endemic, because they were classified as "nearthreatened" by Collar et al. (1994).

We recorded 309 species on our surveys, of which 67 were winter visitors or passage migrants and one was a monsoon visitor (Pied Crested Cuckoo Clamator jacobinus). The remaining species are potentially resident in Kerala, although breeding has not been proven for all of them. A few migrants are South Asian endemics, but none are disjuncts or Western Ghats endemics: we have not dealt with any non-residents except the Wood Snipe Gallinago 
nemoricola (threatened) and Tytler's Leaf Warbler Phylloscopus tytleri, (near-threatened).

\section{Species accounts}

The following abbreviations are used throughout: SAE, South Asian Endemic; WGE, Western Ghats Endemic; ID, Isolated Disjunct; QD, Quasi-disjunct; SV, WV, summer and winter visitors; $R$, residents; LO, lowland; UP, upland; V, vulnerable; NT, near-threatened. Numbers in parentheses give the total number of areas in which the species was recorded.

- Jungle Bush Quail Perdicula asiatica (Figure 3). R, SAE (5). Rare or uncommon where found: a species of dry habitats and hence poorly sampled by our surveys.

- Painted Bush Quail Perdicula erythrorhyncha (Figure 4). R, SAE (13). Common at Periyar East and West, but rare or uncommon elsewhere.

- Red Spurfowl Galloperdix spadicea. R, SAE (22). Found in all areas except Kottayam East and common almost everywhere.

- Grey Junglefowl Gallus sonneratii (Figure 5). R, SAE (19). Uncommon or common everywhere, but probably less so now than in the early years of our surveys. Also seen in coastal areas of Cannanore District but otherwise rare at low altitudes. Suffers from egg collecting and hunting even in protected areas and is probably adversely affected by the removal of forest understorey.

- Indian Peafowl Pavo cristatus. R, SAE (4). A bird of dry country that occurs in Kerala only in border areas: not properly sampled by our surveys.

- Speckled Piculet Picumnus innominatus (Figure 6). R, QD (11). Rare or uncommon wherever found: apparently more widespread north of the Palakkad Gap.

- Rufous Woodpecker Celeus brachyurus (Figure 7). R, QD (17). Common at Parambikulam and Periyar East, uncommon elsewhere: found in all types of forest and also in plantations and gardens.

- White-bellied Woodpecker Dryocopus javensis (Figure 8). R, QD (12). Common at Sultan's Battery and uncommon elsewhere, mainly in mature forest.

- Common Flameback Dinopium javanense (Figure 9). R, ID (22). Found everywhere except at the two northernmost sites: mostly common. Also common throughout lowland Kerala, wherever there are trees.

- Greater Flameback Chrysocolaptes lucidus (Figure 10). R, ID (6). Rare at Periyar East and uncommon elsewhere: usually at mid or high elevations. Perhaps overlooked or mistaken for $D$. javanense in some areas.

- Heart-spotted Woodpecker Hemicircus canente. R, QD (24). Seen in every area surveyed and common in most. Also found outside forest and at all altitudes.

- White-cheeked Barbet Megalaima viridis. R, WGE (24). Common in every area surveyed.

- Crimson-fronted Barbet Megalaima rubricapilla (Figure 11). R, WGE (21). Absent from only three areas, all at low elevations. Common in all but two areas. 

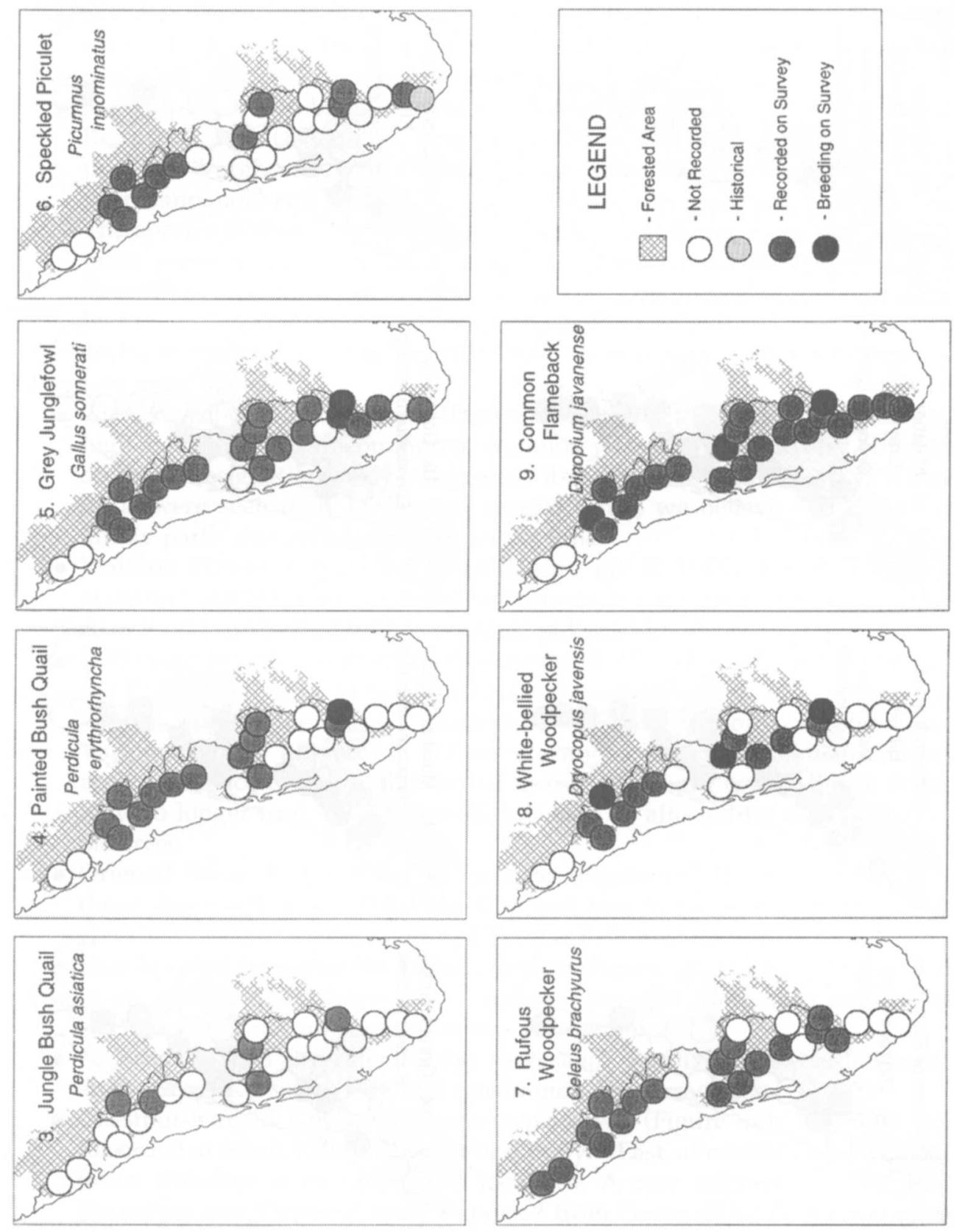

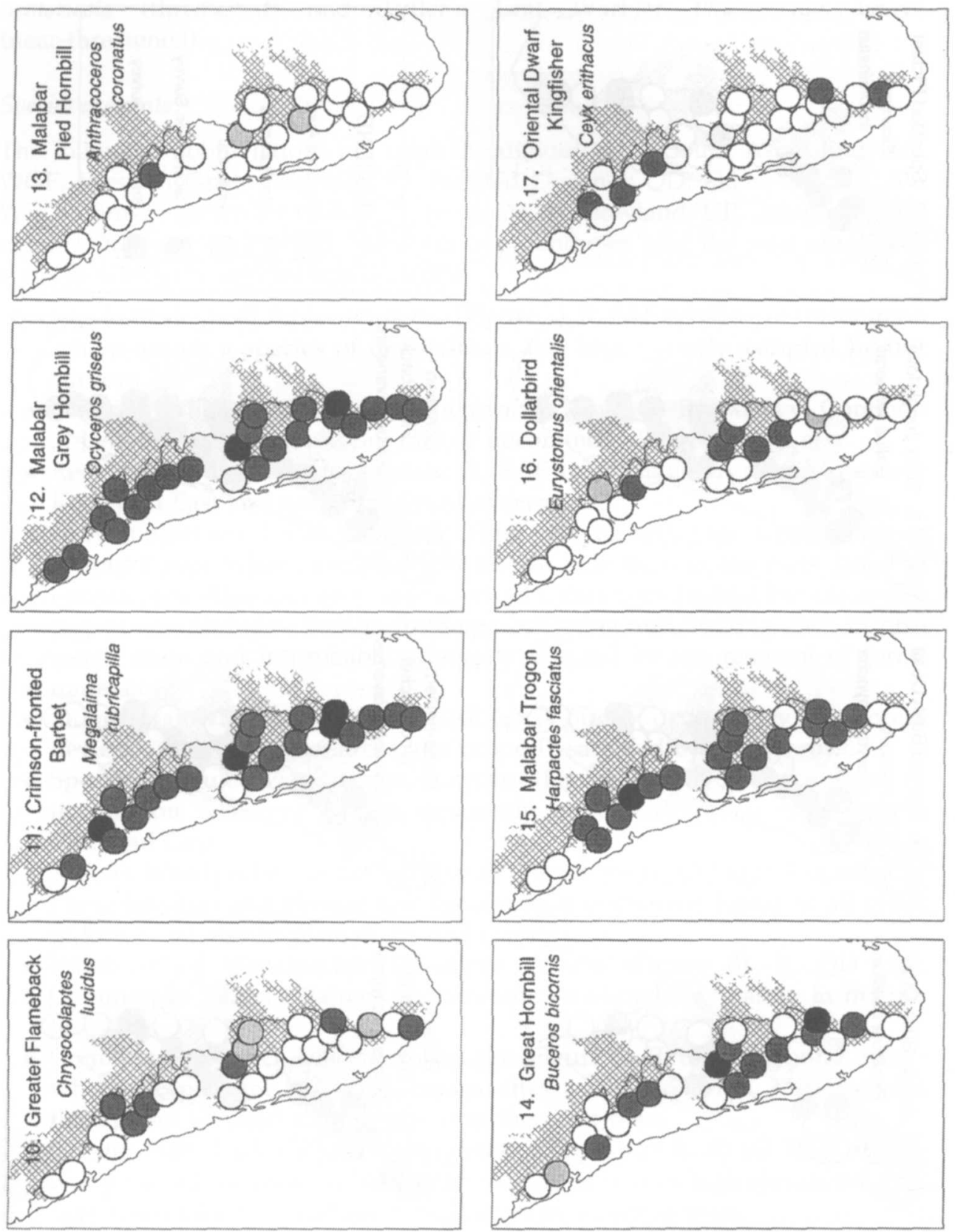
- Malabar Grey Hornbill Ocyceros griseus (Figure 12). R, WGE (22). Recorded everywhere except Trichur Ghats (10) and Kottayam East (18), both low elevation sites, and common in 16 areas.

- Malabar Pied Hornbill Anthracoceros coronatus (Figure 13). R, LO, SAE (1). Recorded only at Nilambur. It was reported as rare at Thattekkad by Sugathan and Varghese (1996). Outside of our study sites, we have recorded it near Cannanore and Calicut feeding in isolated figs away from forest areas. The species is most common at low altitudes and hence is probably under great pressure from habitat destruction. Characterized by Ferguson and Bourdillon (1904) and Ali (1969) as an uncommon species of low elevation, by Stonor (1946) as "not very common" at Parambikulam, and by Kinloch (1921) as common at Nelliampathy, its status in Kerala now appears to warrant great concern.

- Great Hornbill Buceros bicornis (Figure 14). R, ID (11). Found at middle and high elevations and uncommon or common where found, but very obvious, so these designations may exaggerate its status. At Nelliampathy, where birds were seen daily, and often several times, we believe that the same family party was involved nearly every time.

- Malabar Trogon Harpactes fasciatus (Figure 15). R, WGE (17). Widespread, occurring mainly at low to middle elevations, but uncommon in most areas. Also found in the Eastern Ghats (Andhra Pradesh).

- Dollarbird Eurystomus orientalis (Figure 16). R, LO, ID (5). Recorded north of the Palghat Gap only at Nilambur and uncommon everywhere, although it is most likely to be seen at Thattekkad ("not uncommon", Sugathan and Varghese 1996): all records at low elevations. At Parambikulam it was reported as "common in all types of forest" by Stonor (1946): this is definitely no longer true. As a hole nester, it may be affected by the removal of old trees.

- Oriental Dwarf Kingfisher Ceyx erithacus (Figure 17). R, ID (5). Present at three sites north of the Palakkad Gap and two to the south, all at middle elevations: rare everywhere except Periyar East (uncommon).

- Blue-bearded Bee-eater Nyctyornis athertoni (Figure 18). R, QD (5). Recorded in areas of dry deciduous forest, mostly along the Karnataka and Tamil Nadu borders and uncommon or rare everywhere.

- Chestnut-headed Bee-eater Merops leschenaulti. R, QD (23). Recorded in all areas except Kottayam East and uncommon or common everywhere.

- Chestnut-winged Cuckoo Clamator coromandus (Figure 19). WV, QD (3). Recorded at Silent Valley, Munnar and Periyar East, at middle or high elevations. Uncommon or rare at all localities. A rare migrant at Thattekad (Sugathan and Varghese 1996). Reported from Ponmudi by Ferguson (1900) and from Peermade (near Periyar West) by Jackson (1971).

- Blue-faced Malkoha Phaenicophaeus viridirostris. R, SAE (2). Recorded only at Trichur Ghats and Periyar East: a bird of deciduous scrub forest, unlikely to have been common in Kerala at any time.

- Sirkeer Cuckoo Phaenicophaeus leschenaultii. R, SAE (2). Another dry-country species, recorded at Sultan's Battery and Periyar East, in both cases in deciduous woodland close to the state border.

- Red-faced Malkoha Phaenicophaeus pyrrhocephalus. R, V, SAE (o). Not 

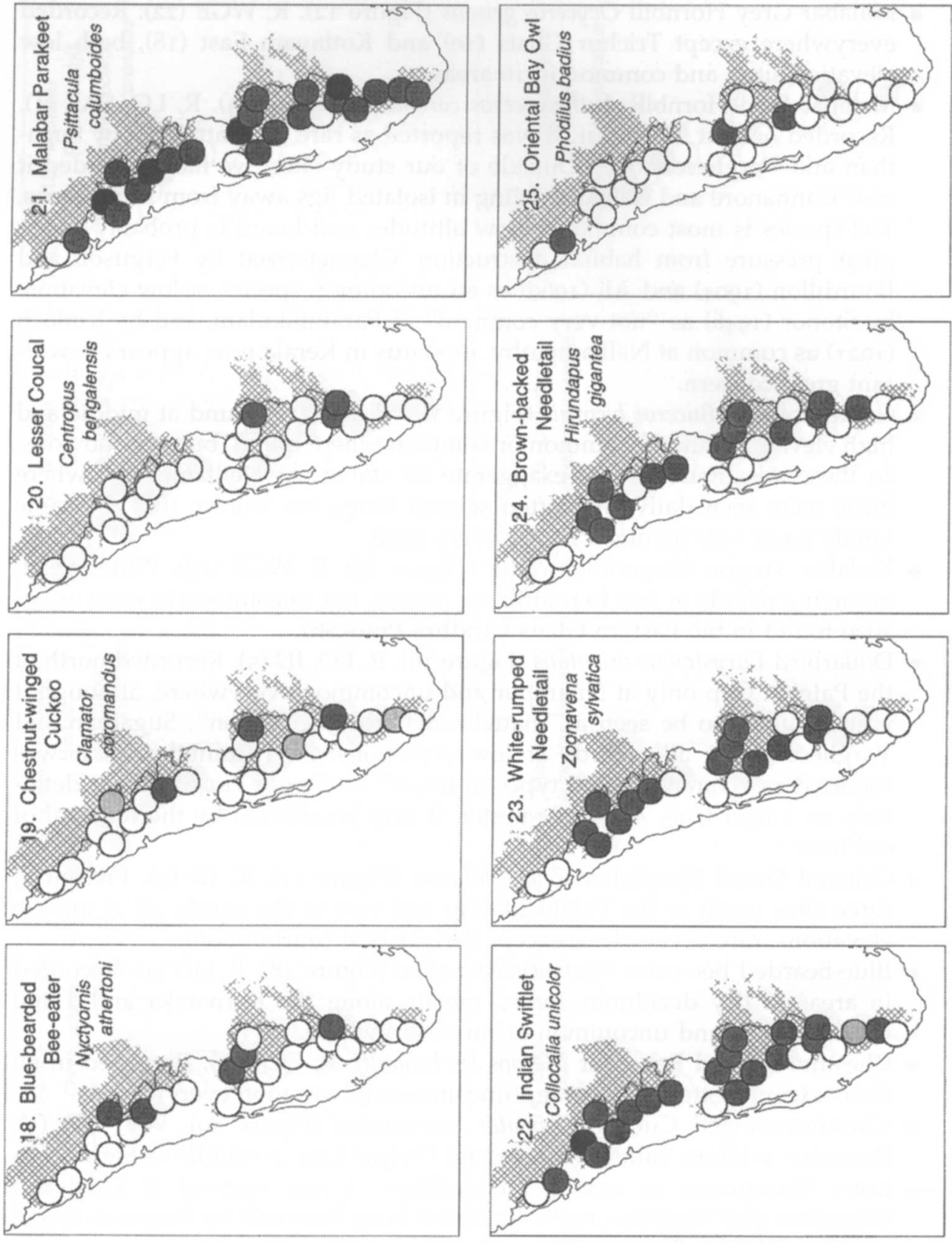
recorded by us and an exceedingly rare bird in India, being mainly confined to Sri Lanka (Ali 1969).

- Lesser Coucal Centropus bengalensis (Figure 20). R, QD (3). Common at Munnar and Periyar East and uncommon at Periyar West. Recorded as rare at Thattekkad by Sugathan and Varghese (1996). Ali (1969) reported it as "not uncommon" in tall grassland intermingled with scrub. This type of habitat may have decreased substantially since the 1930 .

- Vernal Hanging Parrot Loriculus vernalis. R, QD (24). Present and common in all areas.

- Malabar Parakeet Psittacula columboides (Figure 21). R, WGE (21). Common in most areas and absent only from Parappa, Trichur Ghats and Kottayam East, all low elevation areas.

- Indian Swiftlet Collocalia unicolor (Figure 22). R, SAE (18). Absent from only four areas, all at low elevations. Uncommon or common throughout.

- White-rumped Needletail Zoonavena sylvatica (Figure 23). R, QD (13). Common or uncommon at most localities and found mainly at middle or high elevations.

- Brown-backed Needletail Hirundapus gigantea (Figure 24). R, ID (13). Uncommon everywhere except Nelliampathy and Tenmalai, where common: usually at middle and high elevations.

- Grass Owl Tyto capensis. R, ID (o). Not recorded: only two records for Kerala (Ali 1969, Sugathan and Varghese 1996). Recorded from the adjacent Brahmagiris by Davison (1883).

- Oriental Bay Owl Phodilus badius (Figure 25). R, ID (3). First reported in peninsular India in Nelliampathy in 1976 (Hussein and Khan 1977). We obtained one additional record from that area and have mapped two other records that we obtained, although none was collected in the course of our surveys. Both were supported by captive birds/photographs. One bird was also seen at Thottilpalam, between Periya Ghats and Wynaad Ghats. The Konakkad records (two birds) appear to have been the first north of the Palakkad Gap. Both were in plantations. Recorded at Thattakad by Sugathan and Varghese (1996). Although clearly a rare bird in India, the species appears to be more widespread than previous records suggested (Kannan 1.993).

- Spot-bellied Eagle Owl Bubo nipalensis (Figure 26). R, NT, ID (5). Four of the five areas where this species was recorded were north of the Palakkad Gap.

- Brown Wood Owl Strix leptogrammica (Figure 27). R, QD (7). Uncommon in six areas and rare in the seventh: all but two areas were north of the Palakkad Gap.

- Sri Lanka Frogmouth Batrachostomus moniliger (Figure 28). R, WGE (3). Recorded at Tirunelli, where a fledgling was found, Parambikulam and Periyar East. During an intensive survey for this species in 1976, it was recorded at Silent Valley, Parambikulam, Sholayar, Periyar and Thattekad (Sugathan 1981), being noted as a rare breeder at the last site (Sugathan and Varghese 1996). There are historical records from four other localities: its nocturnal habits may mean that it was often overlooked by our surveys.

- Great Eared Nightjar Eurostopodus macrotis. R, ID (2). Recorded at Thattekad (rare) and Periyar East (common), and historically, at Ponmudi and Tenma- 

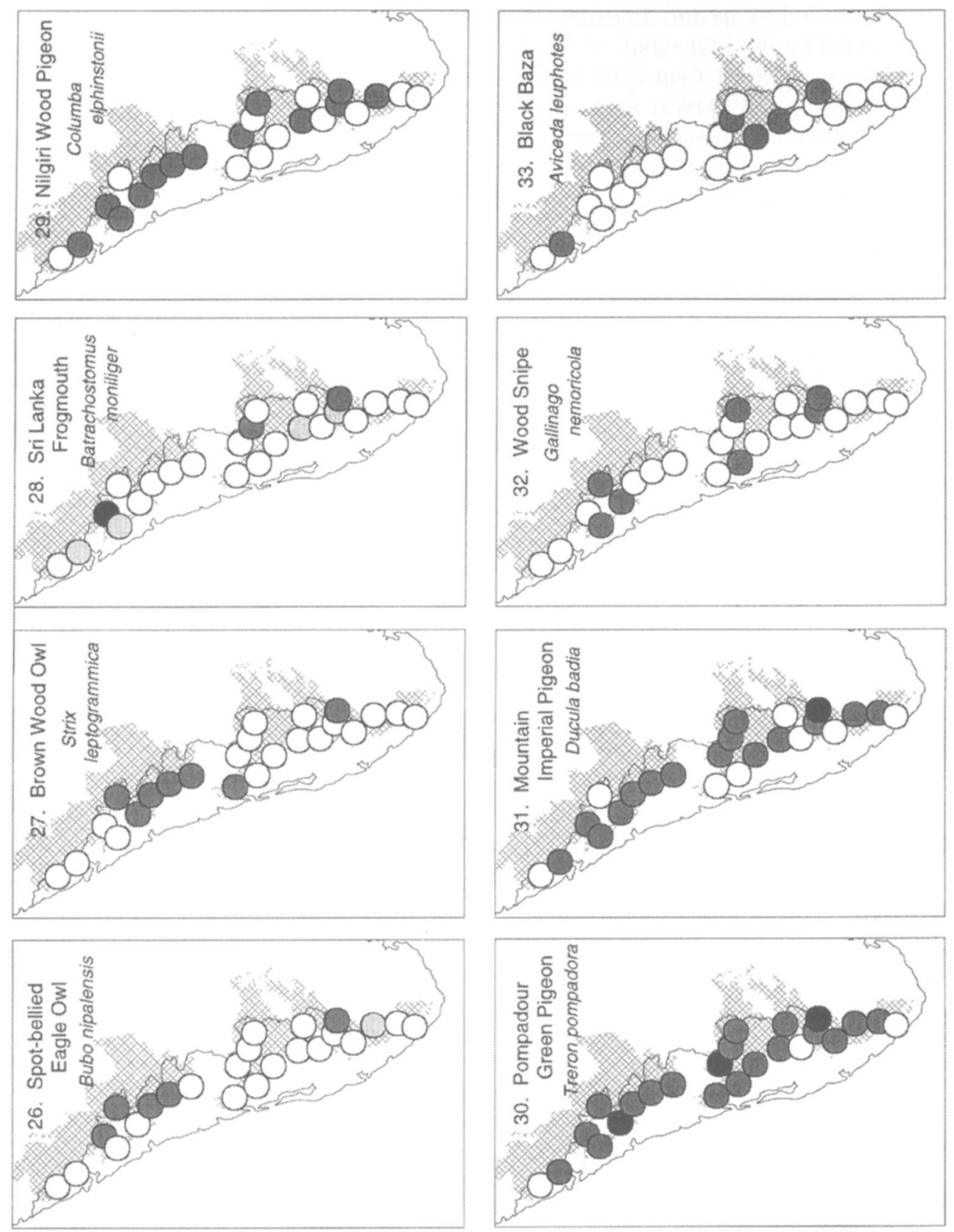
lai. Probably overlooked in some areas. Reported from Thattekad, Parambikulam and Ponmudi by Sugathan and Natarajan (1988). Described by Ferguson and Bourdillon (1904) as "not uncommon about the foot of the hills ... may be seen in flocks"; its status appears to have deteriorated since then.

- Nilgiri Wood Pigeon Columba elphinstonii (Figure 29). R, NT, WGE (13). Uncommon or common, where found.

- Pompadour Green Pigeon Treron pompadora (Figure 30). R, ID (21). Common at most sites, and also found away from forest, wherever there are fruiting figs.

- Mountain Imperial Pigeon Ducula badia (Figure 31). R, ID (16). Common or uncommon, especially at middle and high elevations.

- Wood Snipe Gallinago nemoricola (Figure 32). WV, V (7). Uncommon or rare wherever recorded and apparently most likely to be found in Wynaad (3 areas) and at middle or high elevations (all but one site).

- Jerdon's Baza Aviceda jerdoni. R, ID, NT (1). Recorded only as a single record from the Wynaad Ghats: apparently very rare in Kerala at present. Several nests were reported from southern Kerala in the past century by J. Stewart (Baker 1935), a specimen was obtained in Wynaad (Ali 1969) and Betts (1951) described it as "uncommon" in Coorg. Has been recorded also in the Palni Hills, east of Munnar (Nichols 1944).

- Black Baza Aviceda leuphotes (Figure 33). ID, R (5). Common in Periyar East, but rare elsewhere. For a raptor, not very obvious, foraging within the forest canopy, although sometimes soaring above it. Reported as "not uncommon" at Thattekad by Sugathan and Varghese (1996).

- Grey-headed Fish Eagle Ichthyophaga ichthyaetus (Figure 34). R, NT (9). Uncommon or rare in all areas, but apparently widespread where there are reservoirs or large rivers.

- White-rumped Vulture Gyps bengalensis (Figure 35). R, NT (6). Uncommon: not a forest bird.

- Red-headed Vulture Sarcogyps calvus (Figure 36). R, NT (3). Uncommon or rare, but not a forest bird, so probably poorly represented by our surveys.

- Crested Goshawk Accipiter trivirgatus (Figure 37). R, ID (9). Rare or uncommon in all areas, but a difficult bird to see, spending most of its time perched motionless in dense forest, hence probably under-recorded.

- Besra Accipiter virgatus (Figure 38). R, ID (5). Uncommon in all areas: apparently less widespread than the Crested Goshawk.

- Rufous-bellied Eagle Hieraaetus kienerii (Figure 39). R, ID (4). Common at Nelliampathy (where, surprisingly, it was not reported by Kinloch [1921]), but uncommon elsewhere. As it is usually easy to see, the fact that we did not find it in four areas from which there are historical records suggests that the species range may have contracted, although Ferguson and Bourdillon (1904) considered it rare.

- Mountain Hawk Eagle Spizaetus nipalensis (Figure 40). R, ID (6). Uncommon everywhere and less widespread than the congeneric $S$. cirrhatus.

- Malay Night Heron Gorsachius melanolophus. R, ID (2). This forest heron was seen at Silent Valley and Periyar East, both single birds. One was trapped near Calicut; also reported from Periyar by Robertson and Jackson (1992). Reported "not uncommon" at Nilambur by Kinloch (1923a). 

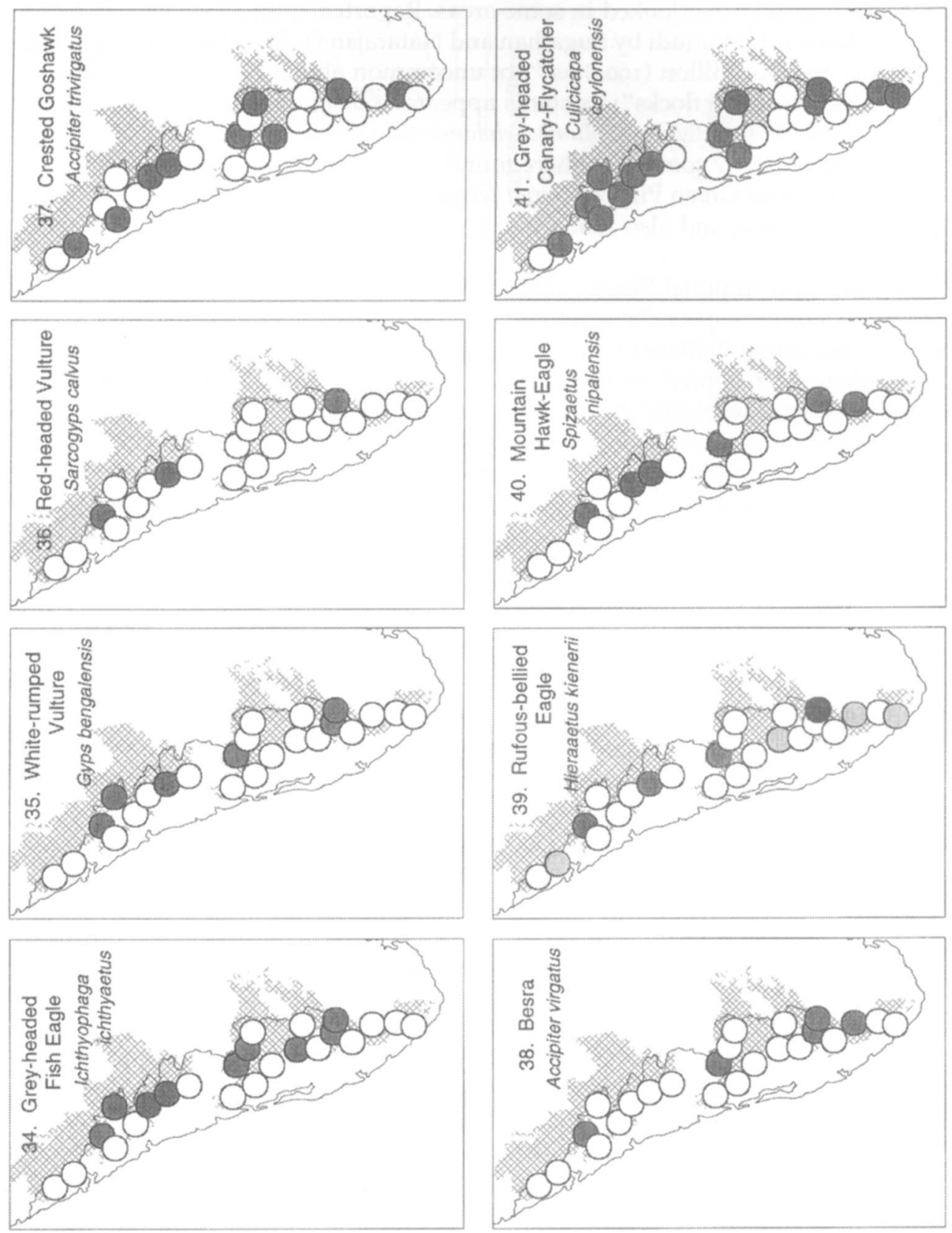
- Greyheaded Canary-Flycatcher Culicicapa ceylonensis (Figure 41). R, QD (14). Uncommon or common: widespread north of Palakkad Gap, less so to the South.

- Asian Fairy Bluebird Irena puella (Figure 42). R, ID (19). Common where found and absent only from some low elevation sites.

- White-bellied Treepie Dendrocitta leucogastra (Figure 43). R, WGE, NT (20). Widespread and uncommon or common everywhere.

- Scarlet Minivet Pericrocotus flammeus (Figure 44). R, QD (20). Common almost everywhere.

- Bar-winged Flycatcher-Shrike Hemipus picatus (Figure 45). R, QD (17). Uncommon or common everywhere and missing only at some low elevation sites.

- White-bellied Drongo Dicnurus caerulescens. R, SAE (2). Recorded only at Sultan's Battery and Parambikulam and uncommon at both sites. Reported as rare at Thattekad (Sugathan and Varghese 1996). Appears to prefer deciduous forest and apparently very local.

- Bronzed Drongo Dicrurus aeneus. R, ID (24). Found everywhere: mostly common.

- Spangled Drongo Dicrurus hottentottus (Figure 46). R, QD (6). Rare or uncommon with four of six areas north of the Palakkad Gap. Recorded at Parambikulam by Vijayan (1978). Mainly found in deciduous forest.

- Large Woodshrike Tephrodornis gularis (Figure 47). R, ID (21). Widespread and mostly common.

- Malabar Whistling Thrush Myophonus horsfieldii. R, WGE (22). Recorded everywhere except Kottayam East and mostly uncommon or common. However, most observers consider that the species is much diminished in the past two decades.

- Scaly Thrush Zoothera dauma (Figure 48). R, ID (2). Recorded only at Silent Valley and Munnar and rare at both sites. Not reported from Thattekad by Sugathan and Varghese (1996), but recorded twice at Topslip in Tamil Nadu, adjacent to the Kerala border, in the 1990s (Kannan unpubl.). The historical record from Konakkad was actually listed by Davison (1883) as "Brahmagiris". At Nelliampathy, it was reported as "numerous, breeding in every shola" (Kinloch 1923b), but we failed to find it there at all. Generally, it appears to be a rare bird in Kerala, an opinion shared by Ferguson and Bourdillon (1904), although its unobtrusive habits may make it appear rarer than it is.

- Eurasian Blackbird Turdus merula (Figure 49). R, ID (19). Uncommon everywhere, and not found at low elevations.

- White-bellied Shortwing Bracliypteryx major (Figure 50). R, WGE, UP, NT (4). Recorded only at Thirunelli, Nelliampathy, Munnar and Periyar East, all at high elevations. Its skulking habits mean that it may be commoner than it seems, but the range is limited mainly to high-altitude sholas.

- Asian Brown Flycatcher Muscicapa dauurica. R, ID (24). Found at all sites, and common at most.

- Black-and-Orange Flycatcher Ficedula nigrorufa (Figure 51). R, WGE, UP (5). Common at Munnar, but uncommon or rare elsewhere. Confined to highelevation sholas. 

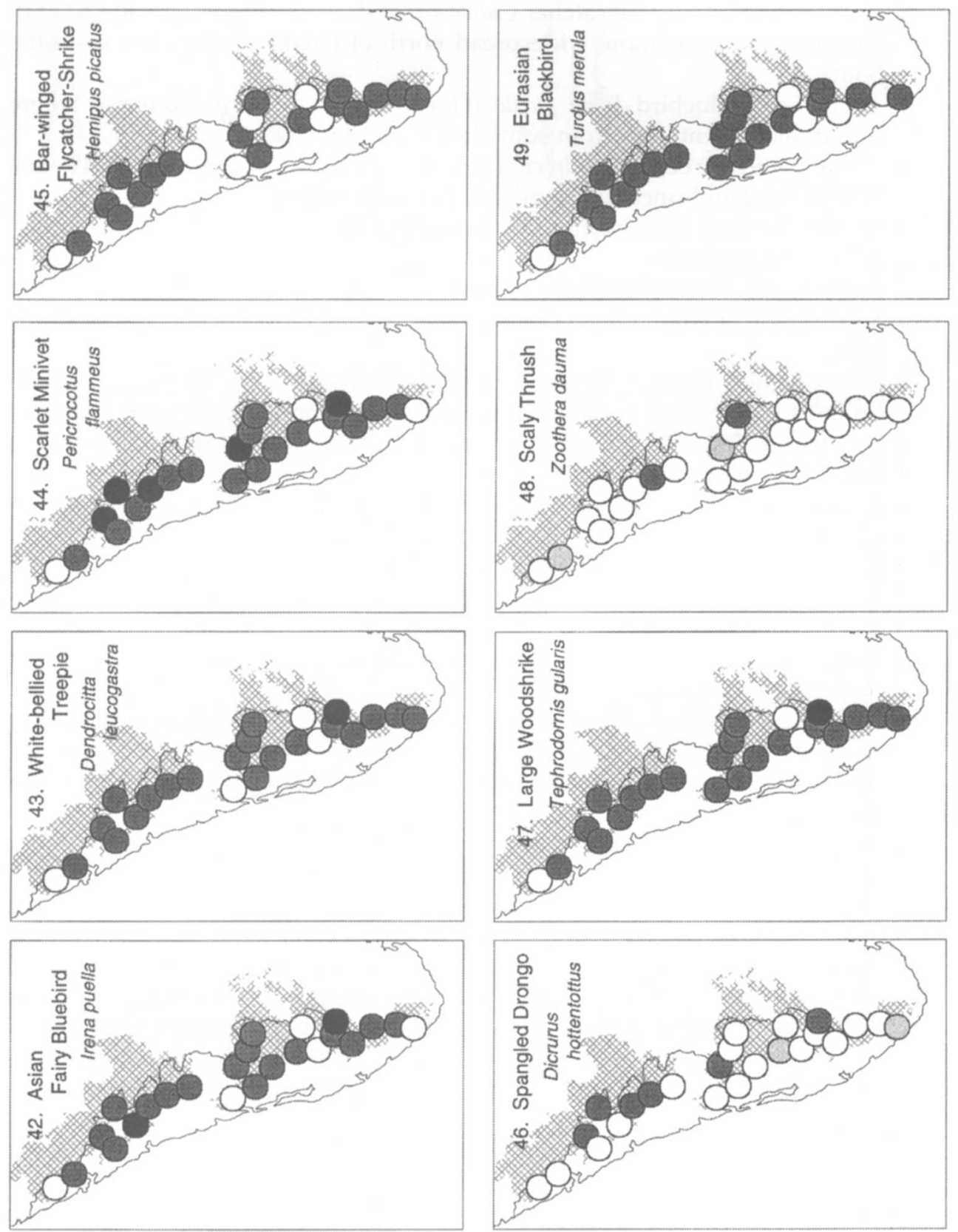

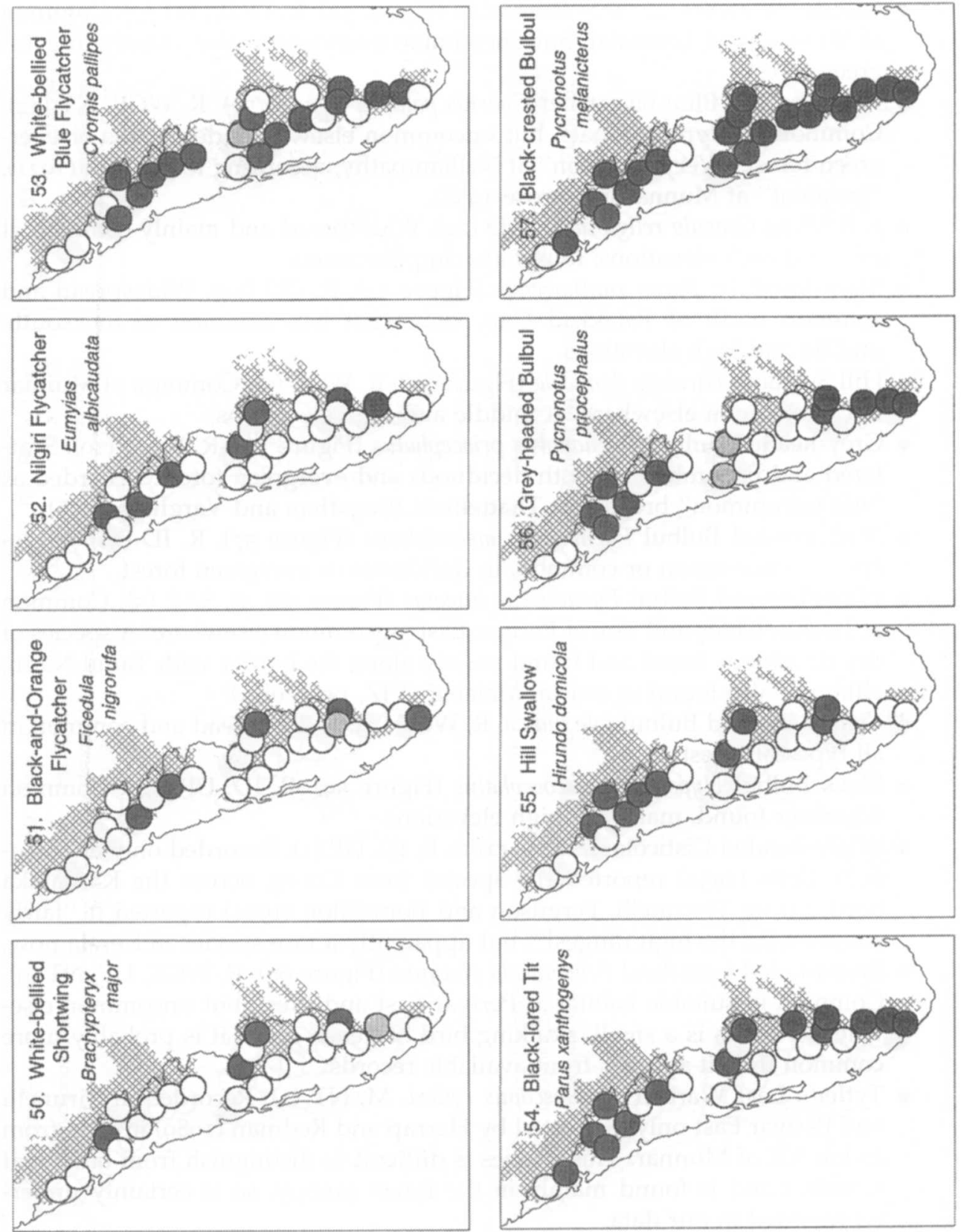
- Nilgiri Flycatcher Eumyias albicaudata (Figure 52). R, WGE, NT (7). Common at Munnar and Tenmalai, but uncommon everywhere else: mainly in evergreen forest.

- White-bellied Blue Flycatcher Cyornis pallipes (Figure 53). R, WGE, NT (14). Common at Wynaad Ghats, but uncommon elsewhere: deciduous or evergreen forest. "Very common" at Nelliampathy, according to Kinloch (1921); "frequent" at Munnar (Primrose 1938).

- Hill Myna Gracula religiosa. R, QD (22). Widespread and mainly common at mid and high elevations: found also in plantations.

- Black-lored Tit Parus xanthogenys (Figure 54). R, QD (14). Widespread and common north of Palakkad Gap, somewhat less common to the south: middle and high elevations.

- Hill Swallow Hirundo domicola (Figure 55). R, WGE (9). Common at Munnar but uncommon elsewhere, at middle and high elevations.

- Grey-headed Bulbul Pycnonotus priocephalus (Figure 56). R, WGE (10). Scattered and uncommon in both deciduous and evergreen forest. Recorded as "not uncommon" breeder at Thattekkad (Sugathan and Varghese 1996).

- Black-crested Bulbul Pycnonotus melanicterus (Figure 57). R, ID (21). Widespread, uncommon or common, in deciduous or evergreen forest.

- White-browed Bulbul Pycnonotus luteolus (Figure 58). R, SAE (5). Common at Trichur Ghats and rare at Periyar East: uncommon elsewhere. A species of dry deciduous forest and found mainly along the border with Tamil Nadu, although also found in coastal Malabar (VJZ, pers. obs.).

- Yellow-browed Bulbul Iole indica. R, WGE (23). Widespread and common in all types of forest.

- Black Bulbul Hypsipetes leucocephalus (Figure 59). R, ID, UP (14). Common wherever found, mainly at high elevations.

- Bright-headed Cisticola Cisticola exilis. R, ID, UP (1). Recorded only at Thirunelli. Betts (1951) reported the species from Coorg, across the Karnataka border from Thirunelli. Ferguson and Bourdillon (1904) reported it "fairly common [in the high ranges]", but apparently a rare species in Kerala now.

- Broad-tailed Grassbird Schoenicola platyura (Figure 6o). R, WGE, UP, NT (9). Common in suitable habitat at Periyar East and West, but uncommon elsewhere. As this is a small, skulking bird of dense grass, it is probably more common than it appears from available records.

- Tytler's Leaf Warbler Phylloscopus tytleri. M, NT (2). Recorded at Tirunelli and Periyar East only. Reported by Harrap and Redman (1989) in 1985 from $20 \mathrm{~km} \mathrm{NE}$ of Munnar. This species is difficult to distinguish from other leaf warblers and is found mainly in the forest canopy, so is certainly underrepresented in our data.

- Wynaad Laughingthrush Garrulax delesserti (Figure 61). R, WGE (15). Uncommon or common, mainly at middle and high altitudes, although not usually found in the highest sholas $(>1,500 \mathrm{~m})$.

- Rufous-breasted Laughingthrush Garrulax cachinnans. R, WGE, UP, NT (1). Seen only at Silent Valley, where it was uncommon. Most of the higher elevation evergreen forests of the Nilgiris are situated in Tamil Nadu, where this species presumably has its population centred.

- Grey-breasted Laughingthrush Garmulax jerdoni (Figure 62). R, WGE, UP, NT 

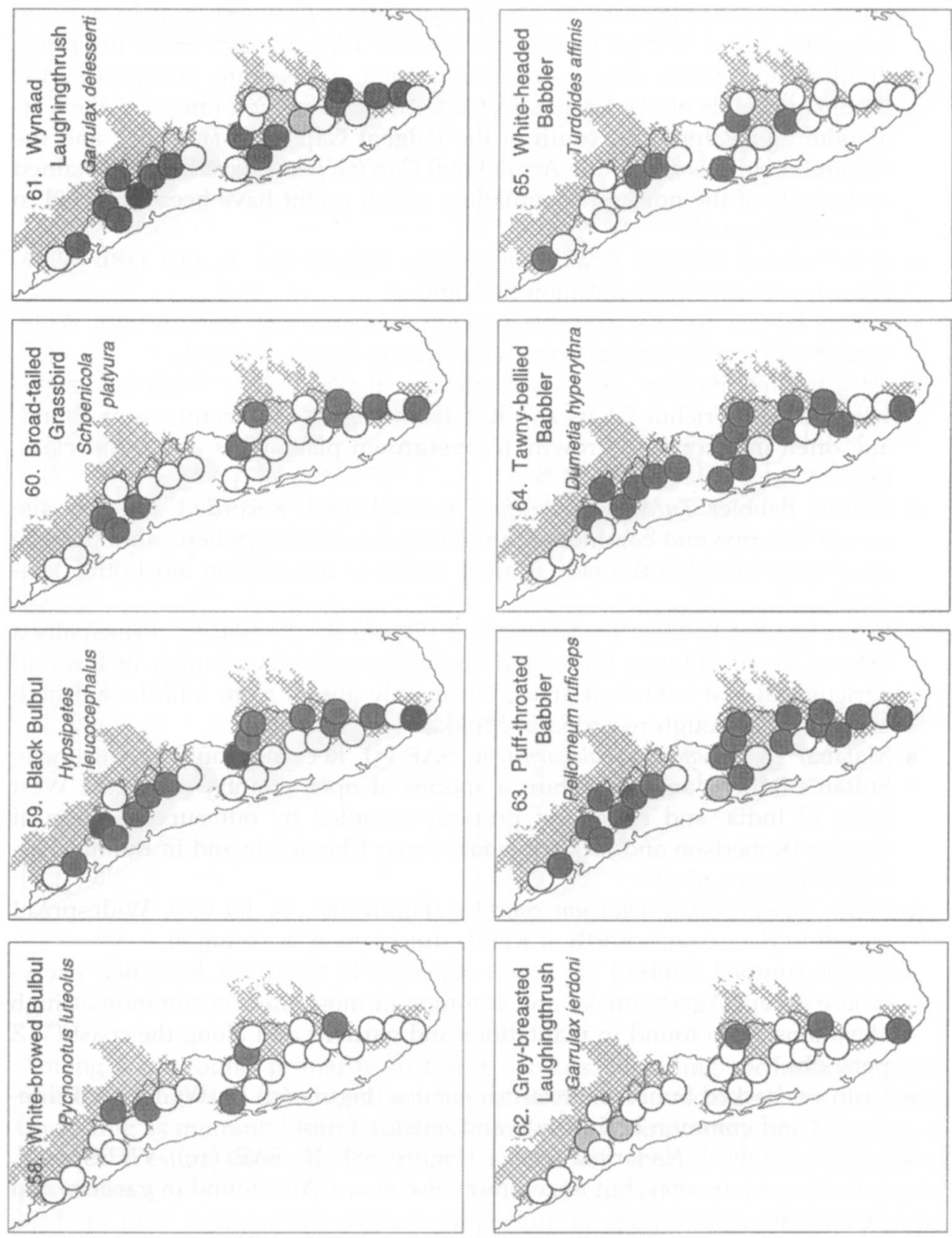
(3). Abundant at Munnar and common at Periyar East and Agastyamalai, in evergreen forest at high elevations. Ali and Ripley (1987) show the range divided into three areas, each supporting a separate subspecies: the Brahmagiri Hills of SW Karnataka (G.j. jerdoni), the high ranges of the Cardamom and Palni Hills, south of the Palghat Gap (G. j. fairbanki), and the Ashambu Hills, south of the Achankovil Gap (G.j. meridionale). We obtained no records of the northern population, which might have been expected to occur in Wynaad.

- Puff-throated Babbler Pellorneum ruficeps (Figure 63). R, QD (18). Widespread, uncommon or common throughout.

- Tawny-bellied Babbler Dumetia hyperythra (Figure 64). R, SAE (17). Widespread and mostly uncommon, in deciduous or mixed forest.

- Dark-fronted Babbler Rhopocichla atriceps. R, WGE (22). Recorded everywhere except Trichur Ghats and Kottayam East, mostly common or abundant: often in secondary growth, in overgrown plantations and forest clearings.

- Rufous Babbler Turdoides subrufus. R, WGE (23). Recorded at every site except Parappa and common or abundant almost everywhere, although the loud unmistakable call made it much easier to record than most other species.

- White-headed Babbler Turdoides affinis (Figure 65). R, SAE (6). Principally a bird of dry deciduous forest and secondary growth, common in lowland agricultural and suburban areas, but mainly absent from middle and high elevations, although recorded at Mukkali (70o m).

- Malabar Lark Galerida malabarica. R, SAE (3). Recorded only at Thirunelli, Sultan's Battery and Nilambur: a species of open country along the West coast of India, and hence not properly sampled by our surveys. Seen at Periyar (Robertson and Jackson (1992), near Khozikode and in Kannur District (VJZ pers. obs.)

- Plain Flowerpecker Dicaeum concolor (Figure 66). R, ID (20). Widespread except in the extreme north of Kerala, uncommon or common.

- Purple-rumped Sunbird Nectarinia zeylonica. R, SAE (23). Recorded everywhere except Agastyamalai and common at most sites: uncommon at high elevations. Also found in plantations and gardens and along the coast (VJZ pers. obs.).

- Crimson-backed Sunbird Nectarinia minima (Figure 67). R, WGE (20). Widespread and common both inside and outside forest.

- Loten's Sunbird Nectarinia lotenia (Figure 68). R, SAE (19). Widespread, common at four sites, but uncommon elsewhere. Also found in gardens and plantations.

- Little Spiderhunter Arachnothera longirostra (Figure 69). R, QD (18). Common or uncommon everywhere: mainly found in moist deciduous forest and adjacent plantations and second growth.

- Nilgiri Pipit Anthus nilghiriensis (Figure 7o). R, WGE, UP (8). Common at most sites: confined to high elevation grasslands, especially above $1,500 \mathrm{~m}$.

- Rufous-bellied Munia Lonchura kelaarti (Figure 71). R, SAE (12). Uncommon or common, found mainly in clearings in forest or along forest margins. 

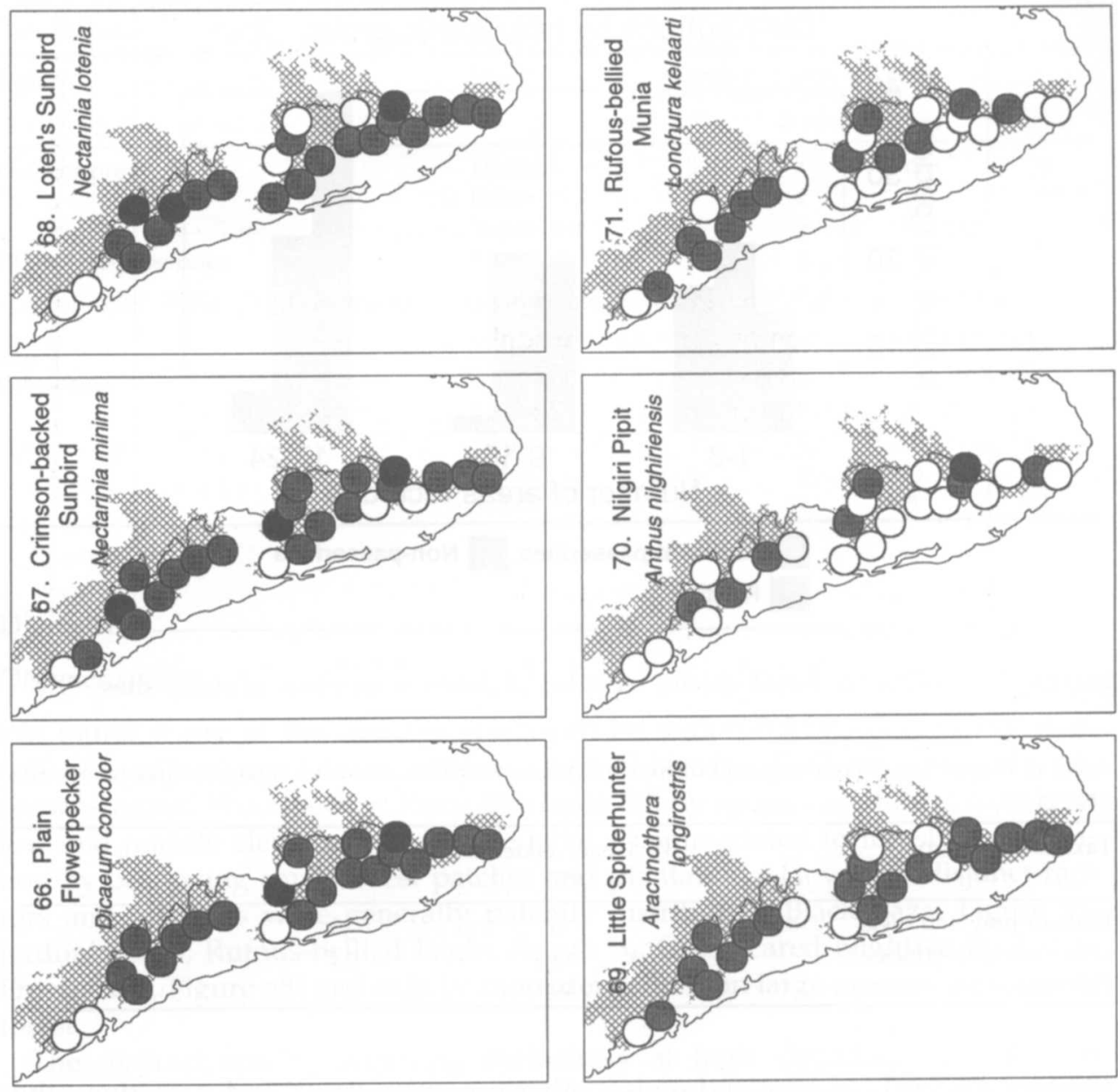

\section{Analysis}

Among birds found primarily in forest habitats, including secondary growth, forest clearings and associated ponds and streams, we recorded 105 passerines (including 25 migrants), and 89 non-passerines, including 25 raptors. The proportions of Western Ghats Endemics among resident species was highest among passerines (19\%, Table 2): none was found among birds of prey. Conversely, birds of prey included the highest proportion of species with disjunct populations in the Western Ghats $(36 \%$, Table 2) and passerines the lowest. "Other non-passerines" were intermediate in both cases. The remaining groups (waterbirds, gamebirds, shorebirds and gulls) were too small for any analysis to be meaningful.

For each forest species, we analysed the proportion of our study sites in which it occurred and compared patterns of occurrence among our taxonomic groups. We used only those groups for which sufficiently large samples were available 


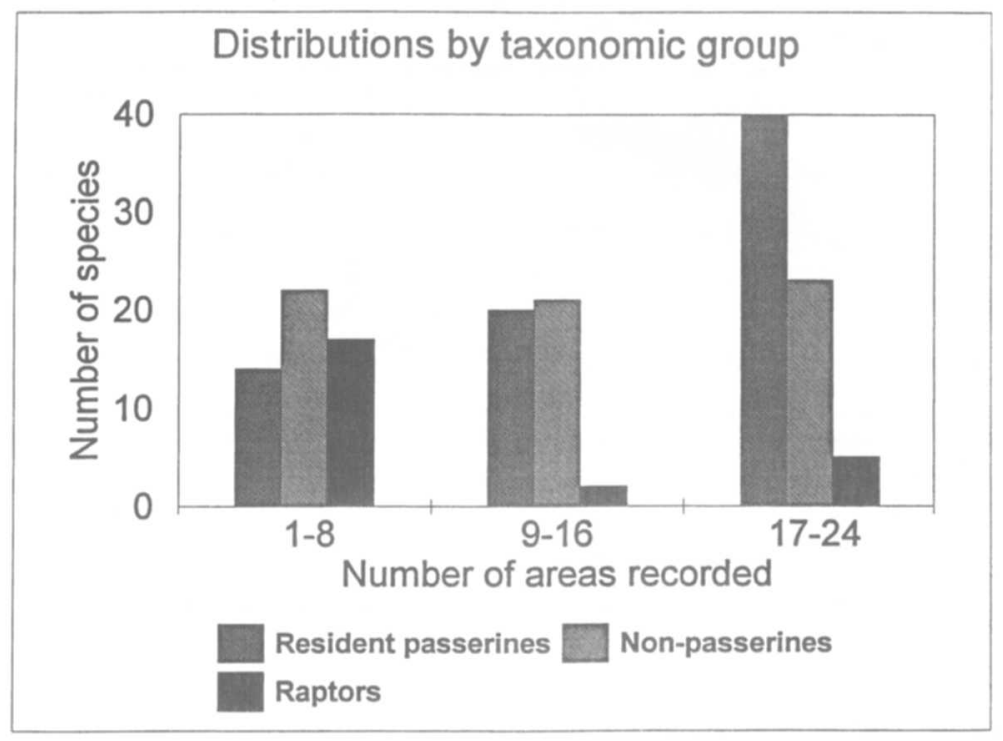

Figure 72. Numbers of forest species recorded at different numbers of study sites.

Table 2. Proportion of endemics and disjuncts among species recorded belonging to three taxonomic groups

\begin{tabular}{lccc}
\hline Taxonomic group & W Ghats endemics & Disjuncts (\%) & $n$ \\
\hline Birds of prey and owls & $(\%)$ & 36 & 25 \\
Other non-passerines & 13 & 34 & 64 \\
Passerines & 19 & 22 & 80 \\
\hline
\end{tabular}

(raptors, i.e. birds of prey and owls, "other non-passerines" and passerines, the last being divided into migrants and non-migrants). In general, raptors, especially disjunct species, occurred in fewer areas than "other non-passerines" and passerines occurred in more areas than either (Figure 72, Table 3).

Among passerines that were neither endemic nor disjunct, non-migrants tended to be more widespread than migrants. Among non-migrants, endemics were less widespread than non-endemics (a higher proportion of endemic species was found at less than nine sites than for other categories; $\chi^{2}=5.13, P=0.023$ ), with disjunct species intermediate. Raptors with disjunct populations were less widespread than those with populations continuous throughout the Indian peninsular $\left(\chi^{2}=4.85, P=0.028\right)$.

A high proportion of Western Ghats Endemics $(39 \%, n=23)$ were found only or predominantly at middle and high altitudes, compared with $6 \%$ of disjunct species $(n=49)$. No resident species that were neither endemic nor disjunct were found predominantly above $500 \mathrm{~m}$ (comparing WGE to $\mathrm{ID}+\mathrm{QD}, \chi^{2},=10.02, P=$ 0.002 ; for $\mathrm{ID}+\mathrm{QD}$ versus others, $\chi_{1}^{2}=2.77$, ns). 
Table 3. Frequency of occurrence of different taxonomic groups in relation to their status (Disjunct, endemic, migrant, or other)

\begin{tabular}{llrrrr}
\hline Group & Status & \multicolumn{3}{c}{ Number of sites recorded } & \multirow{2}{*}{$n$} \\
\cline { 3 - 5 } & & $\mathbf{1 - 8}$ & $9-\mathbf{1 6}$ & $\mathbf{1 7 - 2 4}$ & \\
\hline Birds of prey & Disjunct & 8 & 1 & 0 & 9 \\
& Other & 8 & 2 & 6 & 16 \\
Other non-passerines & Totals & 16 & 3 & 6 & 25 \\
& Endemics & 7 & 2 & 7 & 16 \\
& Disjunct & 7 & 5 & 7 & $\mathbf{1 9}$ \\
& Other & 13 & 11 & 5 & 29 \\
Passerines & Totals & 27 & 18 & 19 & 64 \\
& Migrants & 6 & 9 & 10 & 25 \\
& Endemics & 9 & 6 & $\mathbf{1 0}$ & 25 \\
& Disjunct & 3 & 4 & $\mathbf{1 1}$ & 18 \\
& Other & 5 & 9 & 23 & 37 \\
& Totals & 28 & 54 & 105 & $\mathbf{1 8 7}$ \\
\hline
\end{tabular}

\section{Discussion}

\section{Disjunct species}

We found many of the disjunct species to be widespread (seen at more than $50 \%$ of localities) and common (Brown-backed Needletail, Common Flameback, Brown-capped Woodpecker, Fairy Bluebird). Many species are found mainly at low and middle elevations and some have accommodated to forest fragmentation by occupying small forest patches and plantations. However, disjunct raptors and nightjars were generally patchily distributed (Black Baza, Figure 33; Jerdon's Baza; Rufous-bellied Eagle, Figure 39; Great Eared Nightjar; Sri Lanka Frogmouth, Figure 28) and may be more dependent on large areas of continuous forest.

The disjunct species occurring exclusively at high altitudes, Scaly Thrush (Figure 48) and Eurasian Blackbird (Figure 49), were uncommon and the former was found in only a few localities. Unlike the majority of disjunct populations, which probably originated from the fragmentation of their habitat following climate change (Ali 1949, 1969), these thrushes may have originated from migrant visitors, rather than dispersing from the Himalayas through continuous habitat.

The difference in distribution between disjunct raptors and other disjunct species is striking and may relate to the greater home-range size of raptors. With forests now broken into smaller blocks than formerly, population sizes for many raptors may be insufficient to persist in some areas. The lack of endemism among Western Ghats raptors suggests that they have greater powers of dispersal than many smaller birds and it is likely that their absence from some forest areas is because of limitations on available habitat, rather than difficulties that they experience in recolonizing after local extinction.

\section{Western Ghats endemics}

Compared with other species, a greater proportion of Western Ghats endemics were confined to middle and high altitudes. This difference is probably due to 
the fact that species adapted to higher altitudes have been isolated in the Western Ghats for longer than populations of species occurring at lower altitudes. It is significant that only one species is endemic at the generic level (Broad-tailed Grassbird). A high level of species endemicity, combined with low generic endemicity, is also found among evergreen forest trees in the Western Ghats (Pascal 1988).

The higher-altitude endemics included those confined to grasslands (Broad-tailed Grassbird, Figure 60; Nilgiri Pipit, Figure 70), and to sholas (White-bellied Shortwing, Figure 50; Black-and-Orange Flycatcher, Figure 51; Nilgiri Flycatcher, Figure 52; Grey-breasted Laughingthrush, Figure 62). All of these species were recorded in relatively few localities (all $<50 \%$ of localities), probably because of their restricted altitude range. However, several were common or abundant where found (Nilgiri Pipit, Nilgiri Flycatcher, Greybreasted Laughingthrush). Grasslands and sholas may have been affected less by disturbance and degradation than the forests found at lower altitudes. However, the species involved are all confined to the southern part of the Western Ghats and hence have very restricted ranges, resulting in small global populations.

Some endemic species have adapted to plantations and agricultural landscapes (Crimson-fronted Barbet, Figure 11; Malabar Parakeet, Figure 21; Yellow-browed Bulbul; Rufous Babbler; Small Sunbird; and, to a lesser extent, Malabar Whistling-Thrush; White-bellied Treepie, Figure 43; and White-bellied Blue Flycatcher, Figure 53). These species are generally widespread and common or abundant; none appears to be in any danger of extinction at present..

\section{The status of "threatened" and "near-threatened" species}

Although our surveys were not designed to determine population sizes, we can make some comments on the likely status of those species regarded as rare. We deal specifically with those species occurring in forests and high-altitude grasslands in Kerala that are recorded as "threatened" or "near threatened" by Collar et al. (1994). Under the latest IUCN guidelines (Mace and Stuart 1994), none of those occurring in the Western Ghats are believed to be vulnerable to extinction.

Three species were recorded at more than half of our study sites (Nilgiri Woodpigeon, White-bellied Treepie and White-bellied Blue Flycatcher): all of these were either uncommon or common where found and can be presumed to have substantial populations in Kerala. The White-rumped and Red-headed Vultures are not found in forested areas, except where the forest has been opened up by human activities: their status cannot be assessed from our surveys. Grey-headed Fish Eagles (eight sites) were found on most major water bodies. Their habitat in Kerala has probably been augmented by the creation of many reservoir lakes (Idukki, Thekkady, etc.). The Wood Snipe (seven sites), the only threatened species, is a difficult bird to see, unless flushed, and hence may be more common than it appears.

The remaining species all warrant concern. Jerdon's Baza and Rufous-breasted Laughingthrush, both recorded at only one site, must be considered very rare in Kerala. The Grey-breasted Laughingthrush (three sites) is abundant in a few very limited areas, especially at Munnar. Its continued existence in Kerala is therefore 
very vulnerable to habitat destruction. However, substantial areas of its habitat are within the Eravikulam National Park, which should ensure its continued protection. The status of the White-bellied Shortwing (four sites) and the Nilgiri Flycatcher (seven sites) is similar to that of the Grey-breasted Laughingthrush: all three species are dependent on the continued existence of adequate areas of high-elevation sholas. The same may apply to the Broad-tailed Grassbird (Io sites) which, although found mainly in grasslands, frequents especially those tall grass thickets that develop along the margins of sholas.

The White-bellied Blue Flycatcher (14 sites) is not found exclusively in highelevation evergreen forests and occurring in semi-evergreen forest in places, it appears to be fairly widespread. However, its habitat requirements are not well known and it deserves further study. Likewise the Spot-bellied Eagle Owl (five sites) may be vulnerable to habitat destruction, but little is known about this bird in Kerala.

\section{Additional species of concern}

In addition to the species listed by Collar et al. (1994) we would like to draw attention to the status of several other Western Ghats and South Asian endemics. The Malabar Pied Hornbill (two sites) appears to have a very limited distribution in Kerala and deserves further study. The Sri Lanka Frogmouth (three sites) although probably more widespread than it appears, may be under heavy pressure from habitat destruction. The White-bellied Drongo (two sites) may sometimes be mistaken for Ashy Drongo (a winter visitor), but it appears to be very rare and, being found mainly at lower elevations, is probably very vulnerable to habitat destruction. The Black-and-Orange Flycatcher (five sites) is similar to the White-bellied Shortwing and Nilgiri Flycatcher in being confined to highelevation evergreen forest. We found it common at only one site and it probably warrants careful monitoring.

\section{Overall}

Only a few of the endemic and disjunct birds found in Kerala appear to be in immediate danger of extirpation, and some of these species probably have never been common (Jerdon's Baza, Sri Lanka Frogmouth, Dollarbird, Oriental Dwarf Kingfisher, Rufous-breasted Laughingthrush). The species for which a significant change in status appears to have occurred compared with the assessments given in Ali (1969) are Malabar Pied Hornbill, Lesser Coucal, Great Eared Nightjar, Rufous-bellied Eagle and White-bellied Drongo. It may be significant that all except the Rufous-bellied Eagle are found predominantly at lower altitudes, where habitat alteration has been most intense. We need to stress that the status given by Ali (1969) is often hard to interpret. Hence, other species may have suffered substantial declines in range and abundance without our being able to detect them. We hope that our own surveys will form a more comparable baseline against which future surveys can be compared.

\section{Acknowledgements}

We thank all those, too numerous to mention, who accompanied or assisted us at various times over the past two decades. Special thanks go to Dr Deepakumar 
Narayanakurup of the Kerala State Forest Department and Mr Muhamed Jafer of the Zoological Survey of India for their valuable information and assistance. Miss Sherly Joseph drafted the original maps and Christine Eberl, of the Canadian Wildlife Service, generated the final, computer-drawn versions. We are grateful to the Kerala State Forest Department for providing assistance with access and accommodation in many areas. VJZ would like to thank the British Council, Madras for assistance with travel to the U.K. and Dr C. M. Perrins for providing facilities in the Edward Grey Institute Library, Oxford. We thank T. S. ShankaraRaman for his comments on an earlier draft of the paper. 


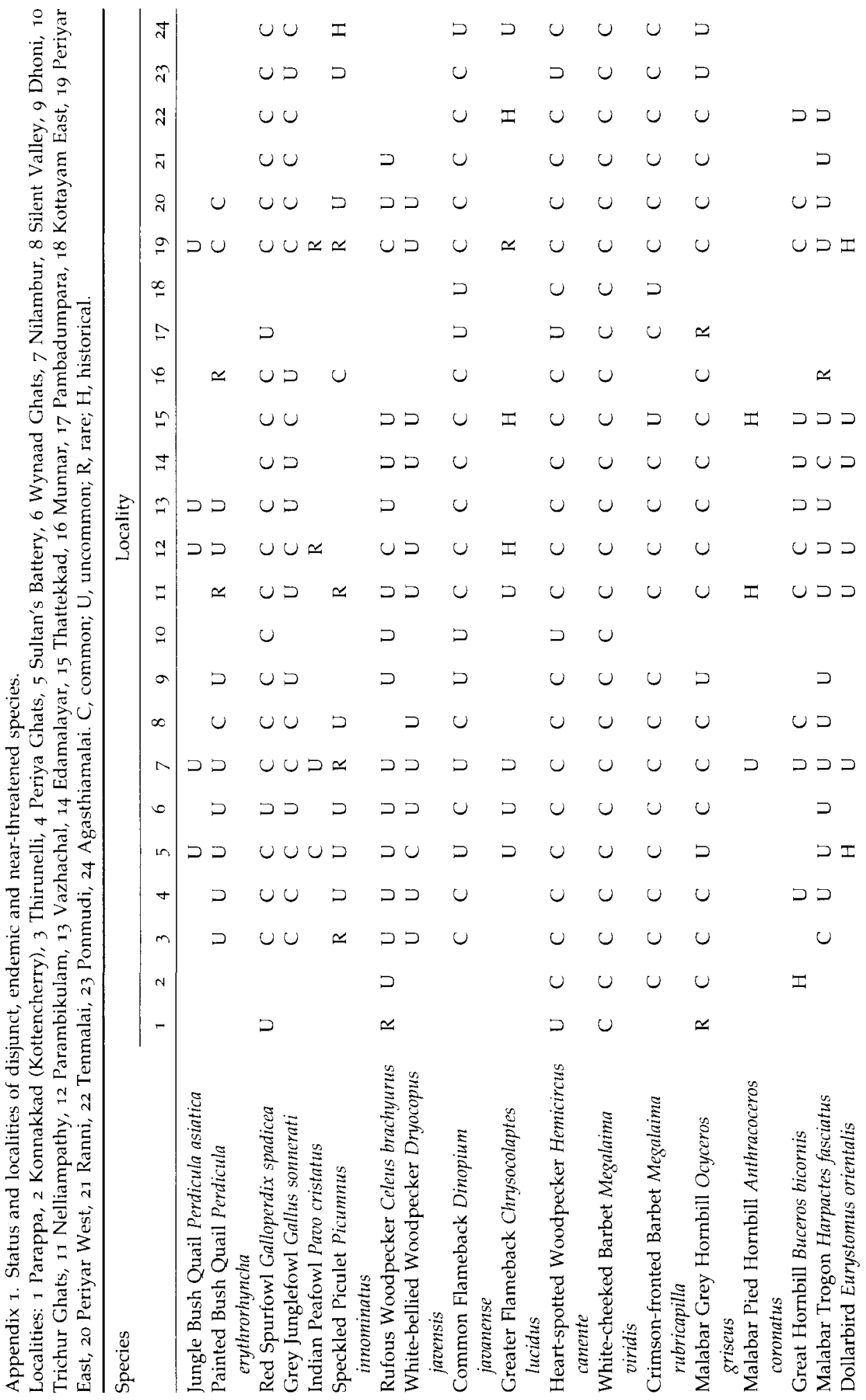




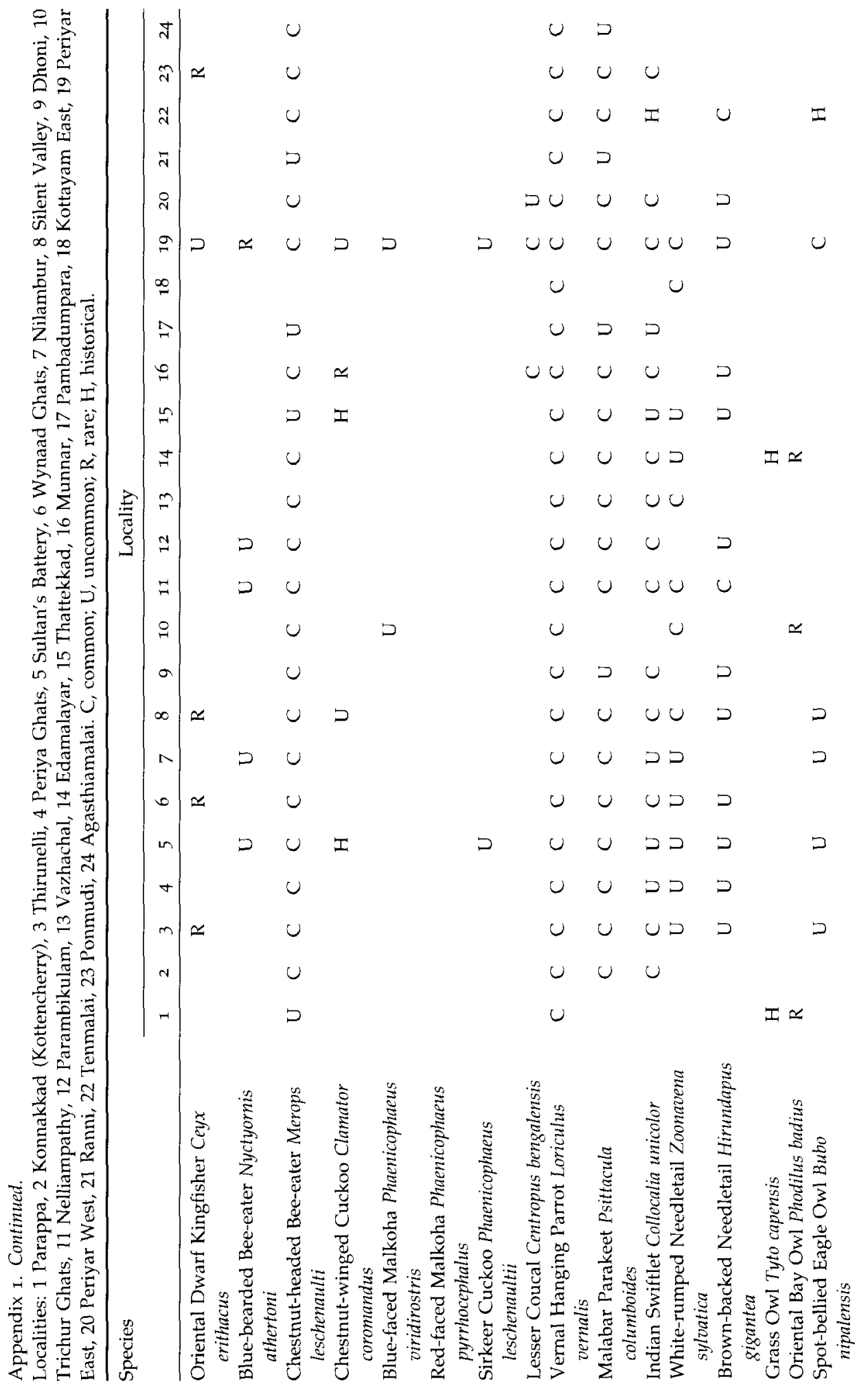




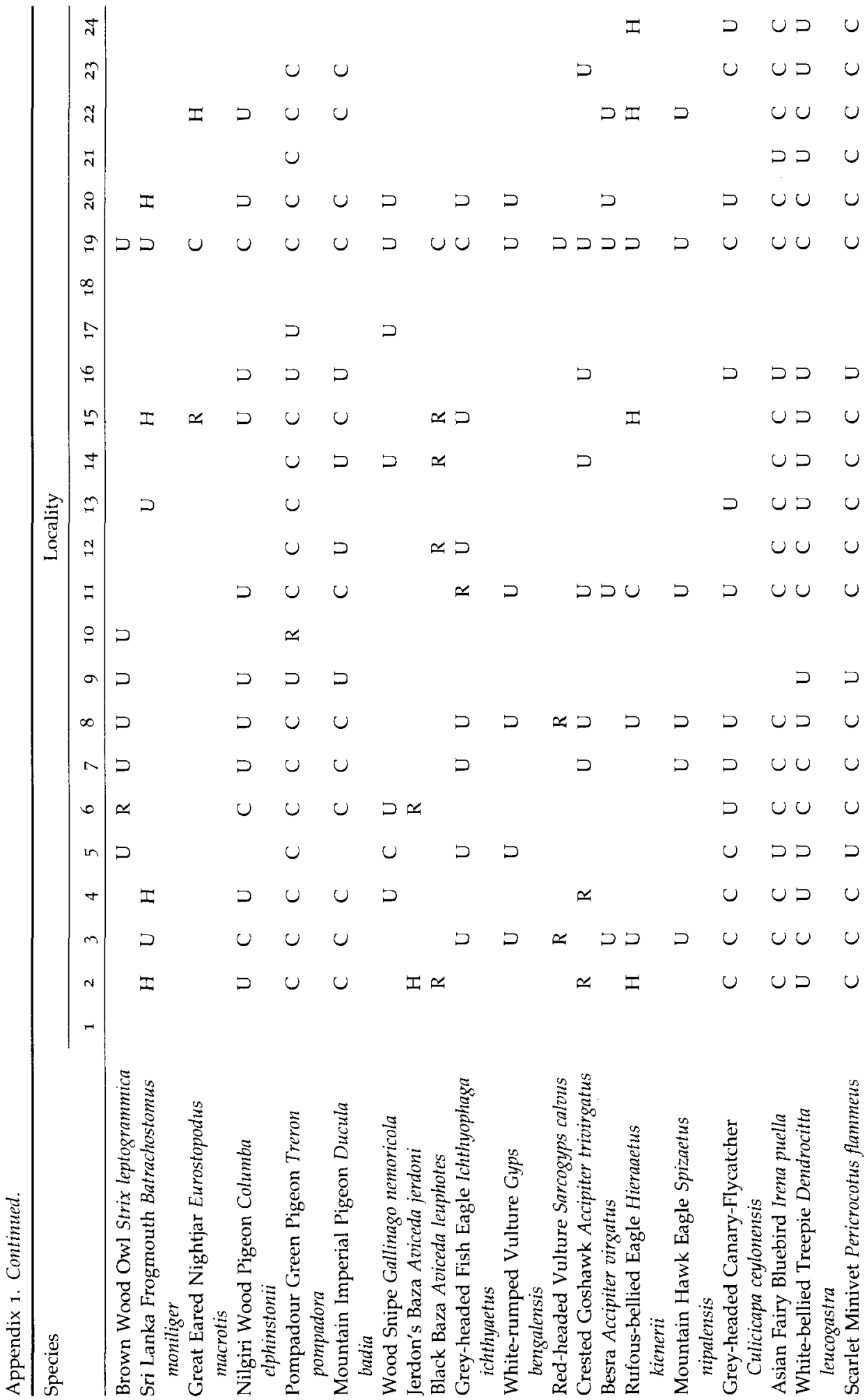




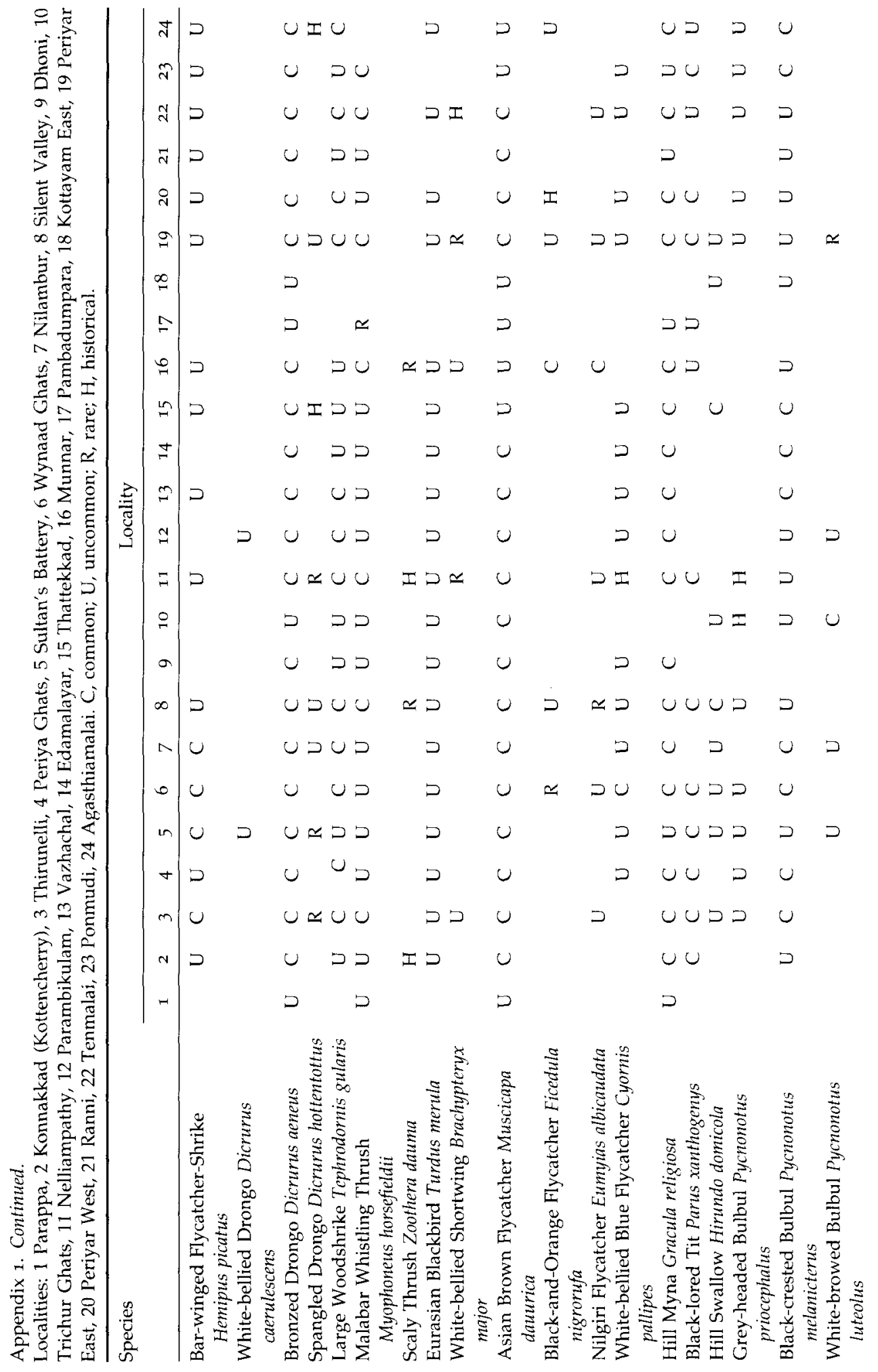




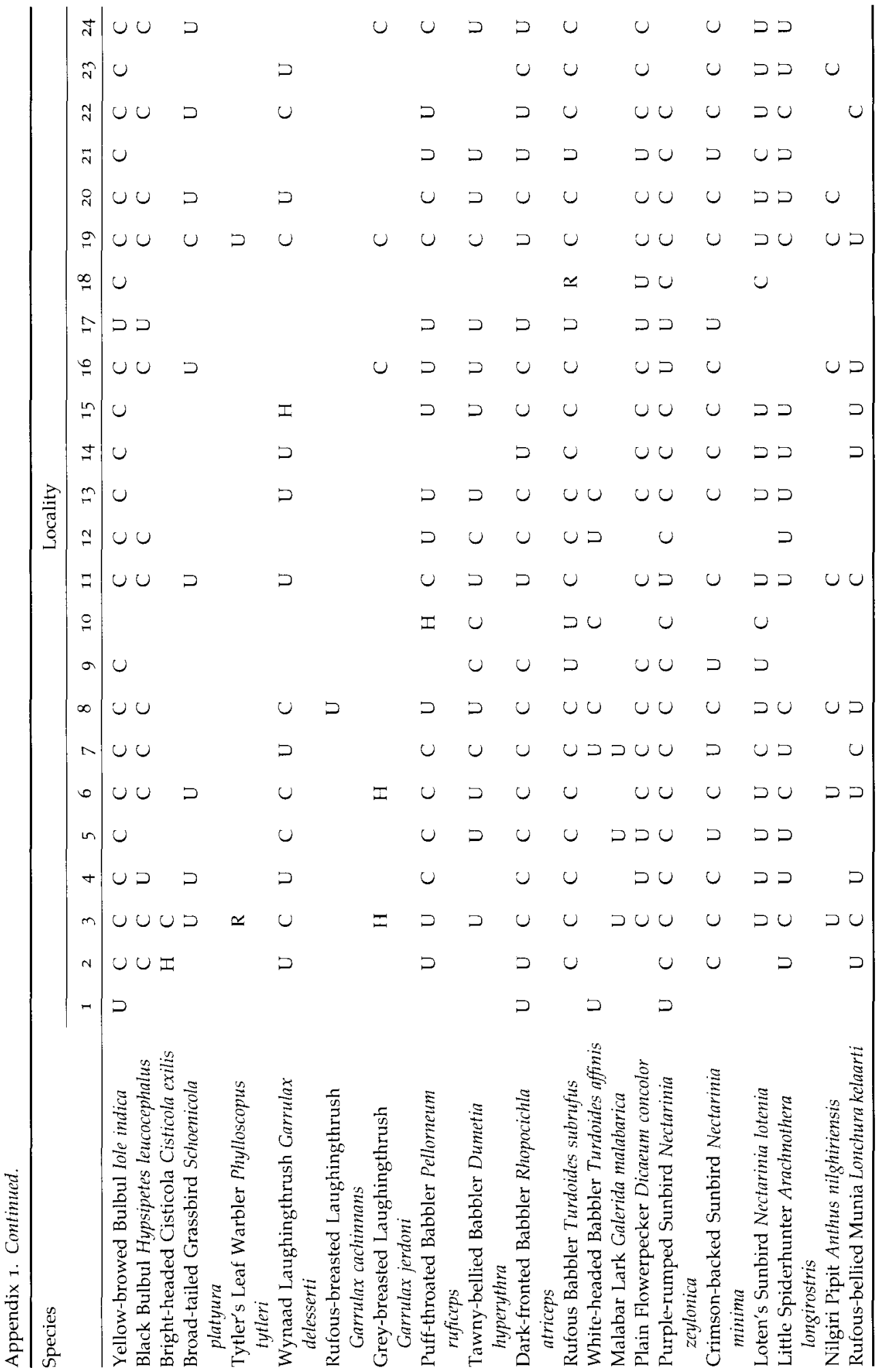




\section{References}

Ali, S. (1949) The Satpura trend as an ornithological highway. Proc. Natl Acad. Sci. India 15: $379-386$.

Ali, S. (1969) Birds of Kerala. Bombay: Oxford University Press.

Ali, S. and Ripley, S. D. (1987) Compact handbook of the birds of India and Pakistan, together with those of Bangladesh, Nepal, Bhutan and Sri Lanka. Second edition. New Delhi: Oxford University Press.

Baker, A. C. S. (1935) Nidification of birds of the Indian empire. London: Taylor and Francis. Betts, F. N. (1951) Birds of Coorg. J. Bombay Nat. Hist. Soc. 50: 20-63, 224-263, 667-684.

Champion, H. G. and Seth, S. K. (1968) A revised survey of the forest types of India. New Delhi: Government of India.

Collar, N. J., Crosby, M. J. and Stattersfield, A. J. (1994) Birds to watch 2. The world list of threatened birds. Cambridge, U.K.: Birdlife International (Birdlife Conservation Series 4).

Daniels, R. J. R. , Joshi, N. V. and Gadgil, M. (1990) Changes in bird faunas of Uttara Kannada, India, in relation to land use over the past century. Biol. Conserv. 52: 37-48.

Davison, W. (1883) Notes on some birds collected in the Nilghiris and in Wynaad and parts of southern Mysore. Stray Feathers 10: 329-419.

Ferguson, H. S. (1900) Birds not recorded from Travancore in "The Fauna of British India". J. Bombay Nat. Hist. Soc. 12: 202-203.

Ferguson, H. S. and Bourdillon, T. F. (1904) The birds of Travancore, with notes on their nidification. J. Bombay Nat. Hist. Soc. $15: 455-474,654-673 ; 16: 1-18$.

Gaston, A. J. and Zacharias, V. J. (1996). The recent distribution of endemic and disjunct birds in Kerala State: preliminary results of an ongoing survey. I. Bombay Nat. Hist. Soc. 93: $389-400$.

Harrap, S. C. and Redman, N. J. (1989) Some observations of scarce birds in Kerala and Tamil Nadu. J. Bombay Nat. Hist. Soc. 86: 460-461.

Hussein, S. A. and Khan, M. A. R. (1977) A new subspecies of Bay Owl [Phodilus badius (Horsfield)] from Peninsula India. J. Bombay Nat. Hist. Soc. 74: 334-336.

Inskipp, T., Lindsay, N. and Duckworth, W. (1996) An annotated checklist of the birds of the Oriental Region. Sandy, U.K.: Oriental Bird Club.

Jackson, M. C. A. (1971) Random notes on birds in Kerala. J. Bombay Nat. Hist. Soc. 68: $107-114$.

Kannan, R. (1993) Rediscovery of the Oriental Bay Owl Phodilus badius in peninsular India. Forktail 8: 148-149.

Kinloch, A. P. (1921) Rough notes on the avifauna of the Nelliampathy Hills. I. Bombay Nat. Hist. Soc. 27: 939-944.

Kinloch, A. P. (1923a) Further notes on the avifauna of the Nelliampathy Hills. J. Bombay Nat. Hist. Soc. 29: 294.

Kinloch, A. P. (1923b) On the birds of the Nelliampathy Hills. J. Bombay Nat. Hist. Soc. 29: $564-565$.

Mace, G. and Stuart, S. (1994) Draft IUCN Red List categories. Species 21-22: 13-24.

Nichols, E. G. (1944) Occurrence of birds in Madura District. II. J. Bombay Nat. Hist. Soc. 44: $574-584$.

Pascal, J. P. (1988) Wet evergreen forests of the Western Ghats of India. Pondichery, India: Institute Français de Pondichery.

Primrose, J. B. (1938) Supplementary observations on the Munnar section of the ornithological survey of Travancore and Cochin. J. Bombay Nat. Hist. Soc. 40: 500-507.

Randhawa, M. S. (1980) A history of agriculture in India. New Delhi: Indian Council of Agricultural Research.

Robertson, A. and Jackson, M. C. A. (1992) Birds of Periyar. Jaipur: Tourism and Wildlife Society of India. 
Stonor, C. R. (1946) Field notes on the birds of the Anamalai Hills (Cochin). J. Bombay Nat. Hist. Soc. 46: 119-125.

Sugathan, R. (1981) A survey of the Ceylon Frogmouth (Batrachostomus moniliger) habitat in the Western Ghats of India. J. Bombay Nat. Hist. Soc. 78: 309-315.

Sugathan, R. and Varghese, A. P. (1996) A review of the birds of Thattakad Bird Sanctuary, Kerala. J. Bombay Nat. Hist. Soc. 93: 487-506.

Sugathan, R. and Natarajan, V. (1988) Occurrence of Bourdillon's Great Eared Nightjar (Eurostopodus macrotis bourdilloni) at Neriyamangalam, Kerala. J. Bombay Nat. Hist. Soc. 85: 424 .

Vijayan, V. S. (1978) Parambikulam Wildlife Sanctuary and adjacent areas. J. Bombay Nat. Hist. Soc. 75: 888-900.

Zacharias, V. J. and Gaston, A. J. (1993) The birds of Wynaad, southern India. Forktail 8: 11-23.

\section{J. ZACHARIAS}

St Joseph's College, Devagiri, Calicut, Kerala 673 008, India

\section{ANTHONY J. GASTON}

Canadian Wildlife Service, National Wildlife Research Centre, 10o Gamelin Blvd., Hull, Quebec, Canada $\mathrm{KIA} \mathrm{OH}_{3}$ 